\title{
The development from kinetic coefficients of a predictive model for the growth of Eichhornia crassipes in the field. II. Testing and refining the model under field conditions
}

\author{
C. F. MUSIL * and C. M. BREEN**
}

Keywords: Eichhornia crassipes, model validation, water nutrient concentrations

\section{ABSTRACT}

\begin{abstract}
Kinetic cocfficients derived for Eichhornia crassipes (Mart.) Solms under culture conditions of $\mathrm{N}$ and $\mathbf{P}$ limitation were used in the Monod model to identify the limiting nutrient and to predict specific growth rates under conditions of varying water nutrient concentration and air temperature. Predicted data were validated by comparison with specitic growth rates measured for plants growing in loosely and densely crowded populations at two field sites. The use of culture-derived maximum specific growth rates (Umax) in the model resulted in inaccurate predictions of plant growth rates in loosely and densely crowded field populations. The use of field-derived Umax values in the model, however, resultcd in adcquate predictions of plant growth rates in loosely crowded field populations. The incorporation of radiant flux density (diffuse component of the radiant flux) and relative humidity into the model considerably improved its accuracy of prediction. In all cases, specific growth rates were more accurately predicted from the limiting total $\mathrm{N}$ or total $\mathrm{P}$ concentrations, than from other $\mathrm{N}$ or $\mathrm{P}$ fractions, in the water.
\end{abstract}

\section{INTRODUCTION}

Harvesting Eichhornia crassipes (Mart.) Solms (water hyacinth) growing in eutrophied aquatic systems may constitute an effective means of removing nutrients and controlling excessive growth of plants (Boyd, 1970; Yount \& Crossman, 1970). However, to achieve maximum nutrient removal efficiency by $E$. crassipes in a nutrient removal scheme, it is necessary to establish the size of the population required to maintain desirable nutrient concentrations in the water under varying conditions of nutrient loading and climate, and the amounts and frequencies of harvest required to control the population size.

From the kinetic standpoint, it is theoretically feasible to construct a mathematical model for $E$. crassipes from which population sizes, yields, growth rates and frequencies and amounts of harvest, under varying conditions of nutrient loading and climate, can be predicted to control nutrient inputs and excessive growth in eutrophied aquatic systems (Toerien, 1972; Musil \& Breen, 1977). Musil \& Breen (1985) measured the kinctic coefficients, maximum specific growth rate (Umax), half saturation coefficient (Ks) and yield coefficient (Yc) for E. crassipes growing in $\mathrm{N}$ and $\mathrm{P}$ tlimited batch cultures in a greenhouse with the objective of developing a predictive model. This investigation was designed to test the validity of and refine these culture determined kinetic coefficients for predicting growth rates of $E$. crassipes under field conditions. In testing the model, two assumptions were made:

\footnotetext{
- Botanical Research Institute, Department of Agriculture \& Water Supply, Private Bag X101, Pretoria 0001.

*" Botany Department, University of Natal, P.O. Box 375, Pietermaritzhurg 3200 .

+ Nutrients present at concentrations below those required for maximum plant growth and hence restricting the growth rate.
}

(i) That the maximum specific growth rates (Umax), derived under culture conditions of $\mathrm{N}$ and P limitation (Musil \& Breen, 1985), followed the van't Hoff rule, i.e. they approximately doubled for each $10^{\circ} \mathrm{C}$ rise in the temperature, as has been demonstrated for various species of marine and fresh water algae (Goldman, 1972; Goldman \& Carpenter, 1974).

(ii) That the specific growth rate (U) was not limited in a multiplicative or additive manner, but in a threshold mode by the single nutrient in shorter supply. This principle, based on 'Liebig's law of the minimum' that the maximum population size or maximum yield in plant material is controlled by the single factor in shorter supply (Blackman, 1905), has been observed to apply in the regulation of phytoplankton organic production by soluble nutrients (Brandt, cited in Gran, 1912). More recently, this has been extended to include the regulation or control of phytoplankıon growth rate by the limiting nutrient (O'Brien, 1972). Droop (1974), for example, has shown that the growth rate of Monochrysis lutheri growing under $\mathbf{P}$ and $\mathbf{B}_{12}$ limitation in culture is not limited in a multiplicative pattern, but by the single nutrient in shorter supply. Rhee (1978) also surmized that the growth rate of Scenedesmus sp, is limited in a threshold pattern.

Apart from air temperature, seasonal variations in radiant flux density and relative humidity may inf?uence $E$. crassipes growth rate under field conditions. In view of this, two hypothetical, multiplicative expressions were investigated for correcting the predicted growth rates for the effects of radiant flux density and relative humidity respectively. These are defined as follows:

$$
\mathrm{Umax}=\mathrm{A} e^{-\mathrm{E} / \mathrm{R}}(\mathbf{T} \times \mathrm{I}) .
$$

where Umax $=$ maximum specific growth rate $g$ fresh mass $\mathrm{g}^{-1} \mathrm{~d}^{-1} ; \mathrm{T}=$ absolute mean daily air temperature ${ }^{\circ} \mathrm{K} ; \mathrm{I}=$ radiant flux density (diffuse compo- 
nent of the radiant flux) $\mathrm{MJ} \mathrm{m}^{-2} \mathrm{~h}^{-1} ; \mathrm{A}=$ constant day $^{-1} ; \mathrm{E}=$ activation energy cal. mole-1; $\mathrm{R}=$ universal gas constant cal. mole ${ }^{-1}{ }^{\circ} \mathrm{K}^{-1}$

The first multiplicative expression assumed that the effect of radiant flux density on $E$. crassipes growth rate could not be considered independent of the effect of temperature. This is in accordance with the observed interaction between temperature and light intensity in influencing both growth rates and photosynthetic responses of algae (Sorokin, 1960; Sorokin \& Krauss, 1962; Maddux \& Jones, 1964; Smayda, 1969; Eppley, 1972; Harris \& Lott, 1973) and higher plant species (Pisek et al., 1973; Billings, 1974). Several environmental modellers (Di Toro et at., 1971; Chen \& Orlob, 1972; Park et al., 1975; Kieffer \& Enns, 1976) have used a multiplication of independent light and temperature functions in phytoplankton population/productivity models, in many instances without expcrimental evidence. Rodhe (1948, 1978) suggested that the combined effects of factors such as temperature, light and daylength on the population dynamics of phytoplankton may be more important than the effect of any single one factor.

$$
\mathrm{U} \max =A e^{-E / R}(\mathrm{~T} \times \mathrm{i} \times \mathrm{RH})
$$

where Umax $=$ maximum specific growth rate $g$ fresh mass $\mathrm{g}^{-1} \mathrm{~d}^{-1} ; \mathrm{T}=$ absolute mean daily air temperature ${ }^{\circ} \mathrm{K} ; \mathrm{I}=$ radiant flux density (diffuse component of the radiant flux) $\mathrm{MJ} \mathrm{m}^{-2} \mathrm{~h}^{-1} ; \mathrm{RH}=$ mean daily relative humidity $\% ; \mathrm{A}=$ constant day ${ }^{-1} ; \mathrm{E}=$ activation energy cal. mole-1; R = universal gas constant cal. mole-1 ${ }^{\circ} \mathrm{K}-1$.

The second multiplicative expression assumed that the observed effect of relative humidity on $E$. crassipes growth rate (Freidel et al., 1978) could not be considered independent of the effect of temperature and radiant flux density. This is because of the interaction between temperature, light intensity and relative humidity in influencing transpiration rates (Crafts et al., 1949) which in turn may indirectly influence growth rate, possibly by altering the water potential (Slayter, 1967; Meidner \& Sheriff, 1976) of leaf cells. Cell and leaf growth are highly sensitive to a reduced water potential, particularly as cell expansion is caused by the action of turgor pressure upon 'softened' cell walls (Greacen \& Oh, 1972). In fact, Hsiao et al. (1976) show that even mild water stress in mesophytic leaves, i.e. where the water potential of leaf cells is reduced by only a few bars, can result in a reduction in growth rate and the disruption of several metabolic processes, including protein and chlorophyll biosynthesis.

\section{LOCALITIES AND METHODS}

\section{Sites}

Two sites, characterized by different nutrient concentrations in the water, were selected for field estimations of specific growth rates. These rates, measured periodically throughout the year, were compared with those predicted by the use of culture-derived kinetic coefficients (Musil \& Breen, 1985) in the Monod model. The sites are in the Durban District of Natal (Fig. 1) in the climatic region described by Schulze (1965) as warm to hot and humid, subtropical. The Maturation Pond 3 (MP3) site is enriched by secondary treated waste-water effluent discharged from the northern sewage treatment works and the Botanic Gardens Lake (BGL) site by fertilizer run-off.

\section{Measurement of growth}

Specific growth rates were measured by tagging plants and introducing them for 12 to 14 day periods into field populations (Bock, 1966; 1969). These rates were measured in both loosely and densely crowded field populations. Mitsch (1977) found that the two different growth forms, viz marginal and central forms (Musil, 1982), associated with these two different population densities (Rao, 1920; McClean, 1922; Lansdell, 1925; Bruhl \& Gupta, 1927; La Garde, 1930; Weber, 1950) exhibit different net carbon uptakes and photosynthesis/respiration ratios which suggests that they may have different growth rates under similar field conditions.

Vegetatively propagated offsets (daughter plants) possessing three pseudolaminae of the marginal (fresh mass: ca 7 to $22 \mathrm{~g}$ ) and central (fresh mass: ca 47 to $111 \mathrm{~g}$ ) forms were collected at 12 to 14 day intervals from loosely and densely crowded populations at each site. Plants were washed in site water, to remove all extrancous particles, tagged and allowed to drain for two minutes. They were shaken to dislodge adhering water, their fresh masses recorded on an electric, top-loading balance and introduced into enclosures. Two sizes of enclosures were used. Both were constructed of plastic-coated wire mesh held in place by metal fencing posts driven into the sediment. To minimize disturbance by wind and wave action, they were located on the leeward side of each water body in water ca 1,0 $\mathrm{m}$ deep.

Cylindrical enclosures with a diameter of ca $1 \mathrm{~m}$ and a height of ca $1,5 \mathrm{~m}$ were used for containing plants of the marginal form at each site. The water area, ca $0,8 \mathrm{~m}^{2}$, contained within each enclosure was adequate to accommodate an increase in the size of the introduced population, over a 12 to 14 day period, without causing the plants to become unduly crowded. Forty plants of the marginal form collected at each site were introduced into four enclosures (10) plants per enclosure) located at each site.

Two densely crowded populations (ca $6 \mathrm{~m}^{2}$ ) of the central form were enclosed by wire mesh, ca 1,5 m high, at the MP3 site. This ensured that the plants within were kept in densely crowded situations and maintained in the central form. Thirty plants of the central form collected at this site were inserted at random ( 15 plants per enclosure) into the two enclosed populations.

After 12 to 14 days, marginal and central forms and their offsets were harvested from the enclosures at each site. Care was taken not to separate the offsets from their respective parents. Plants were picked free of debris, washed and reweighed as described above. Specific growth rates were calculated for marginal and central forms, over each 12 to 14 


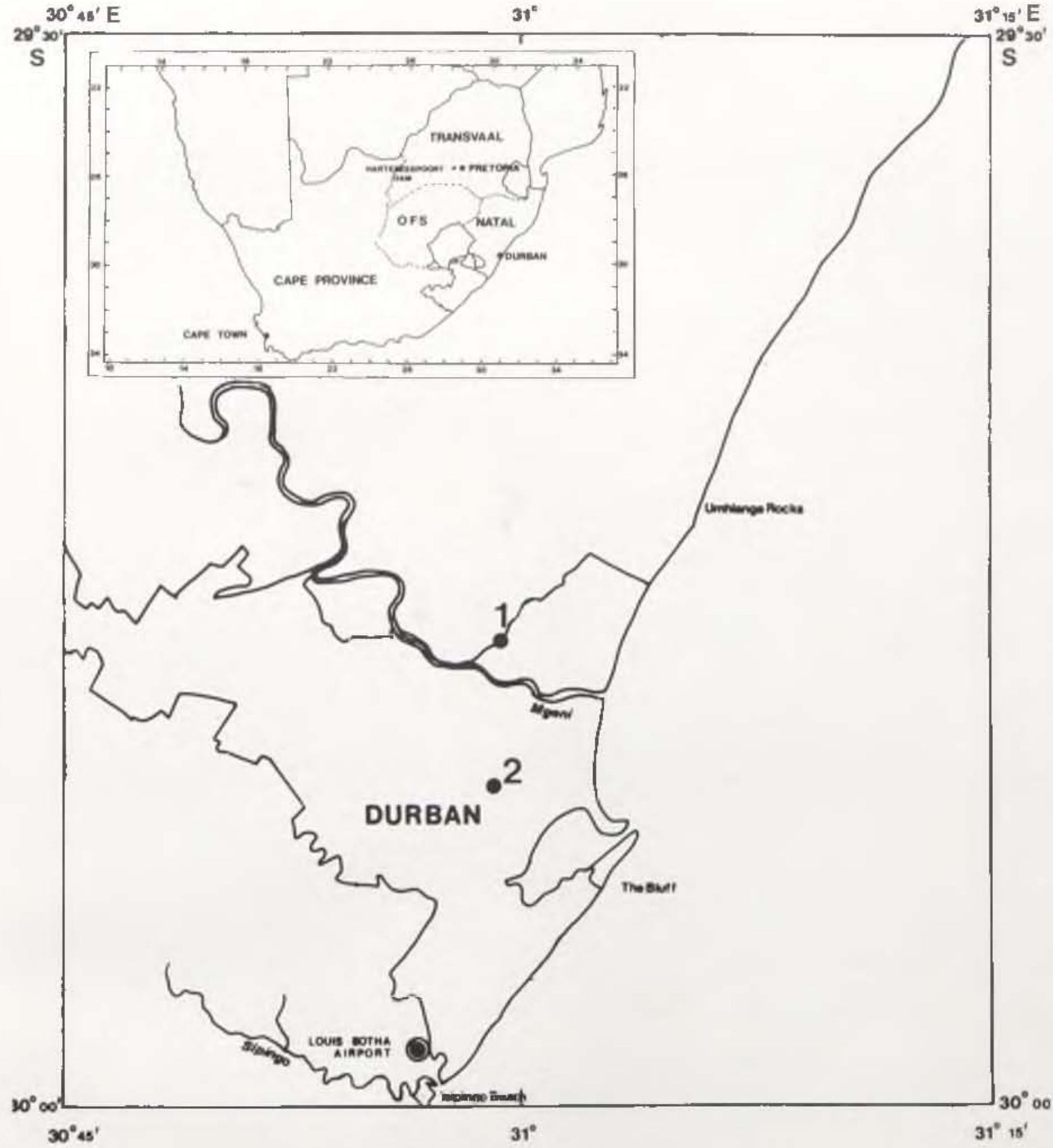

FIG. 1. - Location of field sites. 1, maturation pond, northern sewage treatment works; 2, Botanic Gardens Lake.

day interval, using the general growth equation (Malek \& Fencl, 1966; Radford, 1967):

$$
U=\frac{\ln X_{1}-\ln X_{0}}{t}
$$

where $\mathrm{Xo}_{0}=$ fresh mass at time $=t_{1}(\mathrm{~g}) ; \mathrm{Xt}=$ fresh mass at time $=\mathrm{t}_{2}(\mathrm{~g}) ; \mathrm{U}=$ specific growth rate $(\mathrm{g}$ fresh mass $\left.g^{-1} d^{-1}\right) ; t=$ time period between time $t_{2}$ and $\mathrm{t}_{1}$ (days); $\ell_{\mathrm{n}}=\log _{e}$ (natural logarithm).

\section{Chemical analyses}

Water samples were collected between $11 \mathrm{~h} 00$ and $14 \mathrm{~h} 00$ from within the loosely and densely crowded populations enclosed at each site, at the commencement and termination of each growing interval. Water samples were collected ca $20 \mathrm{~cm}$ below the water surface, to avoid surface contamination, in 500 $\mathrm{ml}$ plastic bottles (Golterman, 1969) previously cleaned with conc. $\mathrm{HCl}$ and rinsed thoroughly in deionised-distilled water. Bottles were sealed with Parafilm (American Can Company, Greenwich, Connecticut) and immediately transported in an insulated container to the laboratory.

The following $\mathrm{N}$ and $\mathrm{P}$ fractions were analysed in the water samples using published methods (Environmental Protection Agency, 1974; American Public Health Ass.: Standard methods, 1975). In filtered samples (Rigler, 1964; Olsen, 1967; Golterman, 1969), nitrate-nitrogen $\left(\mathrm{NO}_{3}-\mathrm{N}\right)$ by colorimetry after reduction to nitrite and soluble reactive phosphorus (SRP) (Twinch \& Breen, 1980) by colorimetry using the molybdenum blue method. In unfiltered samples, Kjeldahl nitrogen as ammonium $\left(\mathrm{NH}_{4}-\mathrm{N}\right)$ after digestion of the samples by conc. $\mathrm{H}_{2} \mathrm{SO}_{4}$ in the presence of a mercury catalyst and 
total phosphorus (total P) as SRP after digestion of the samples with $\mathrm{H}_{2} \mathrm{SO}_{4}$ and persulphate. Total nitrogen (total $\mathrm{N}$ ) was calculated as the sum of Kjeldahl nitrogen and nitrate plus nitrite $\left(\mathrm{NH}_{4}-\mathrm{N}+\right.$ $\mathrm{NO}_{3}-\mathrm{N}+\mathrm{NO}_{2}-\mathrm{N}$ ).

The $\mathrm{pH}$ of the water was recorded daily between $11 \mathrm{~h}(0)$ and $14 \mathrm{~h}(10$, beneath the loosely and denscly crowded populations enclosed at each site, with an electrolytic probe connected to a portable $\mathrm{pH}$ meter.

\section{Physical analyses}

Over each growing interval, hourly measurements of radiant flux density (diffuse component of the radiant (lux) and daily maximum, minimum and mean air temperatures and relative humidities were obtained from the nearby meteorological station at Louis Botha Airport, Durban.

The diffuse component of the radiant flux was chosen as a measure of the light as this includes a greater proportion of the photosynthetically active radiation. About one-third of the direct solar radiation, often referred to as the global component, is photosynthetically active compared with over twothirds for the diffuse component (Ross, 1975; Fitter \& Hay, 1981). Theoretical calculations have shown that even under cloudless skies, the diffuse radiation (D) may account for between one-third and threequarters of the total irradiance $(\mathrm{T})$, and in a series of

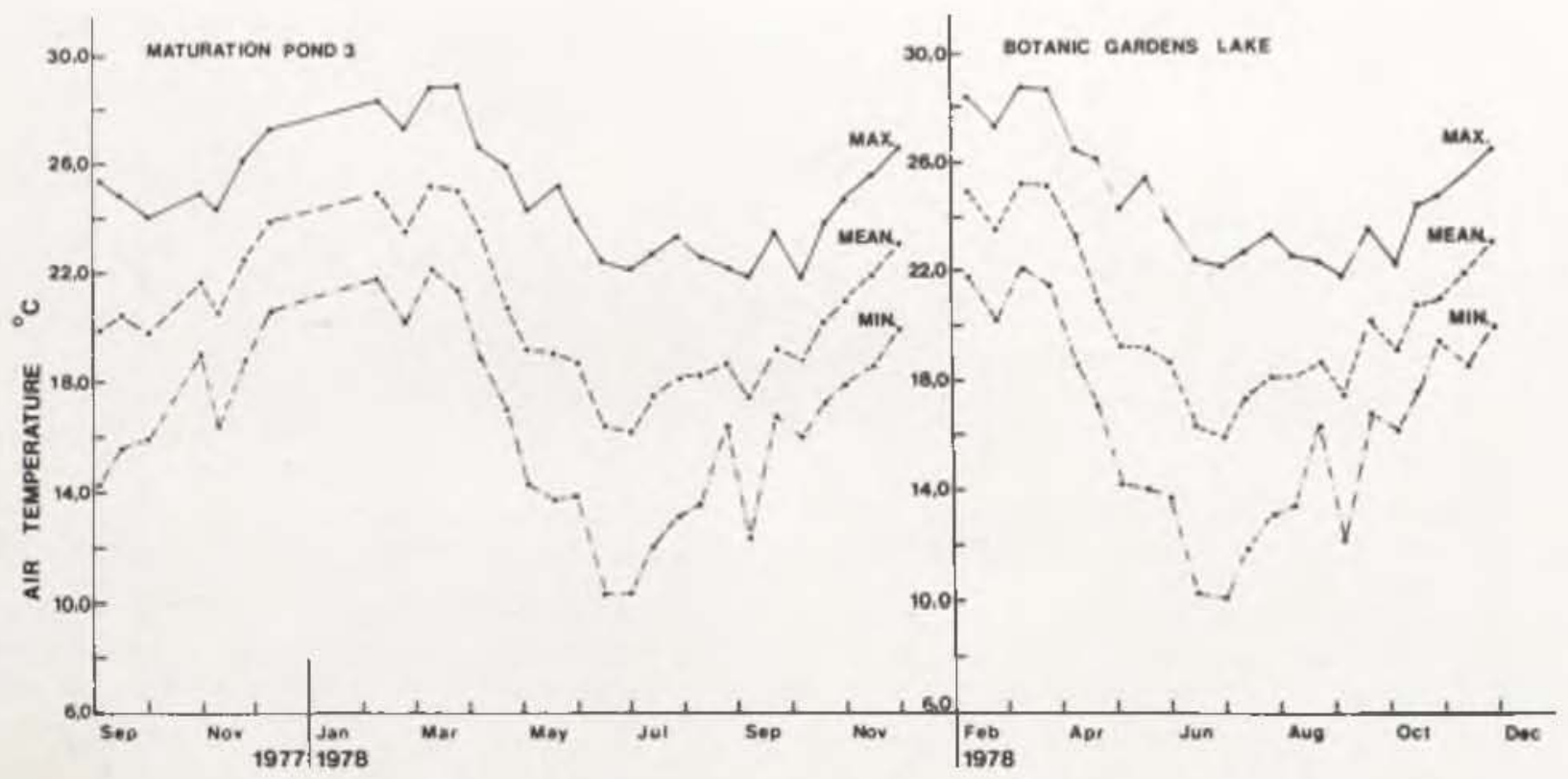

FlG. 2, - Air temperatures, as daily averages over each growing interval, at two field sites.

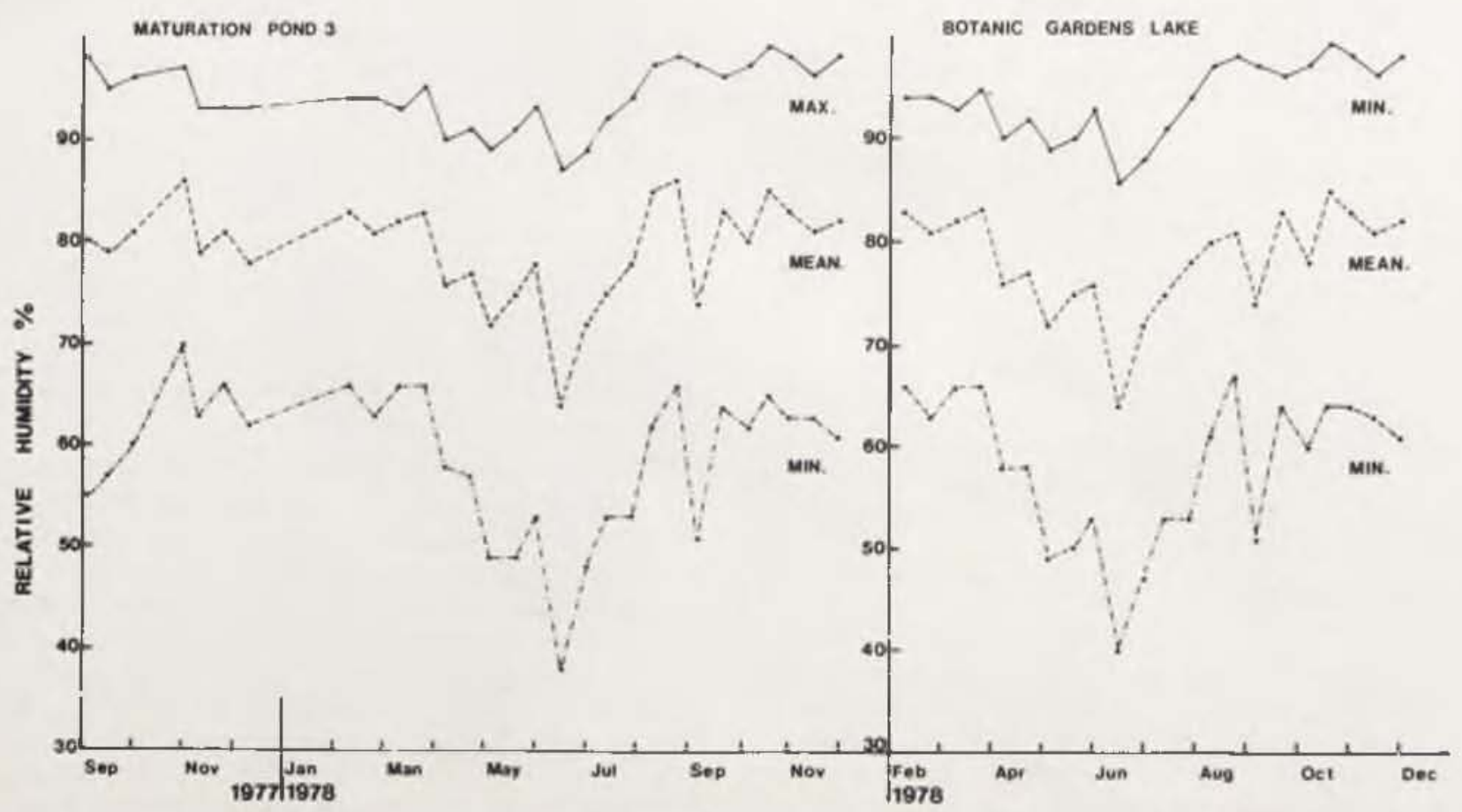

FIG. 3. - Relative humidities, as daily averages over cach growing interval, at two field sites. 


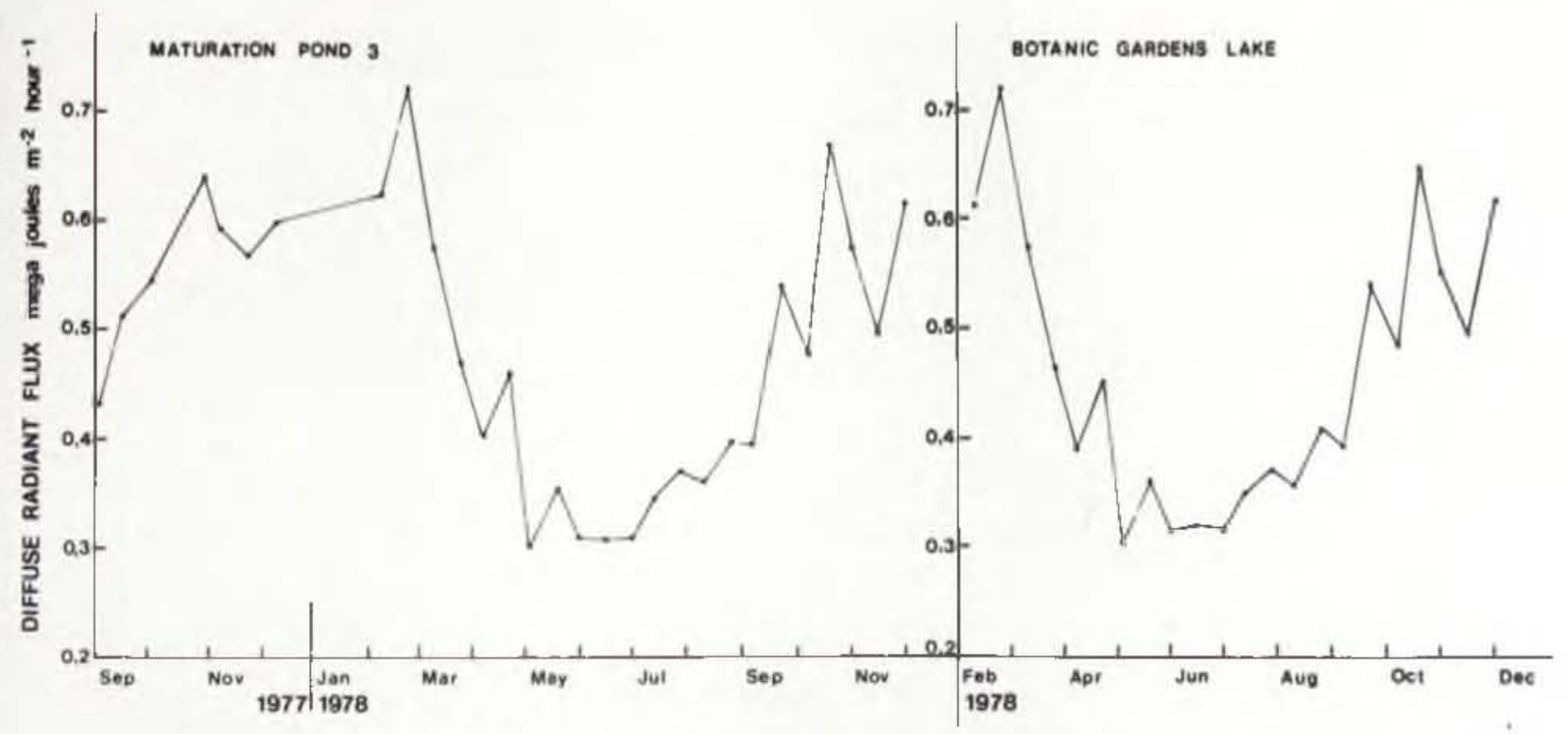

FIG. 4. - Diffuse radiant fluxes, as hourly averages over each growing interval, at two field sites.

measurements Szeiez (1974) showed that the ratio D/T was always greater than 0,5 .

\section{RESULTS AND DISCUSSION}

\section{Field data}

\section{Physical factors}

Air temperatures, relative humidities and diffuse radiant fluxes at the two sites are depicted in Figs 2, 3 \& 4. They showed a seasonal pattern decreasing progressively after summer (September to March) through to winter (May to August). Mean daily air temperatures and relative humidities at the two sites ranged from 16,1 to $25,2^{\circ} \mathrm{C}$ and from 64 to $85 \%$ respectively. Diffuse radiant fluxes ranged from 0,30 to $0,72 \mathrm{MJ} \mathrm{m}^{-2} \mathrm{~h}^{-i}$.

\section{Chemicat jactors}

Nitrogen and $\mathbf{P}$ concentrations in the water and the variation in water $\mathrm{pH}$ beneath the enclosed, loosely crowded populations at the two sites are shown in Figs 5, 6 \& 7.

Total $\mathrm{N}, \mathrm{NH}_{4}-\mathrm{N}, \mathrm{SRP}$ and total $\mathrm{P}$ concentrations in the water at the BGL site were considerably lower than those at the MP3 site, whereas $\mathrm{NO}_{3}-\mathrm{N}$ concen-

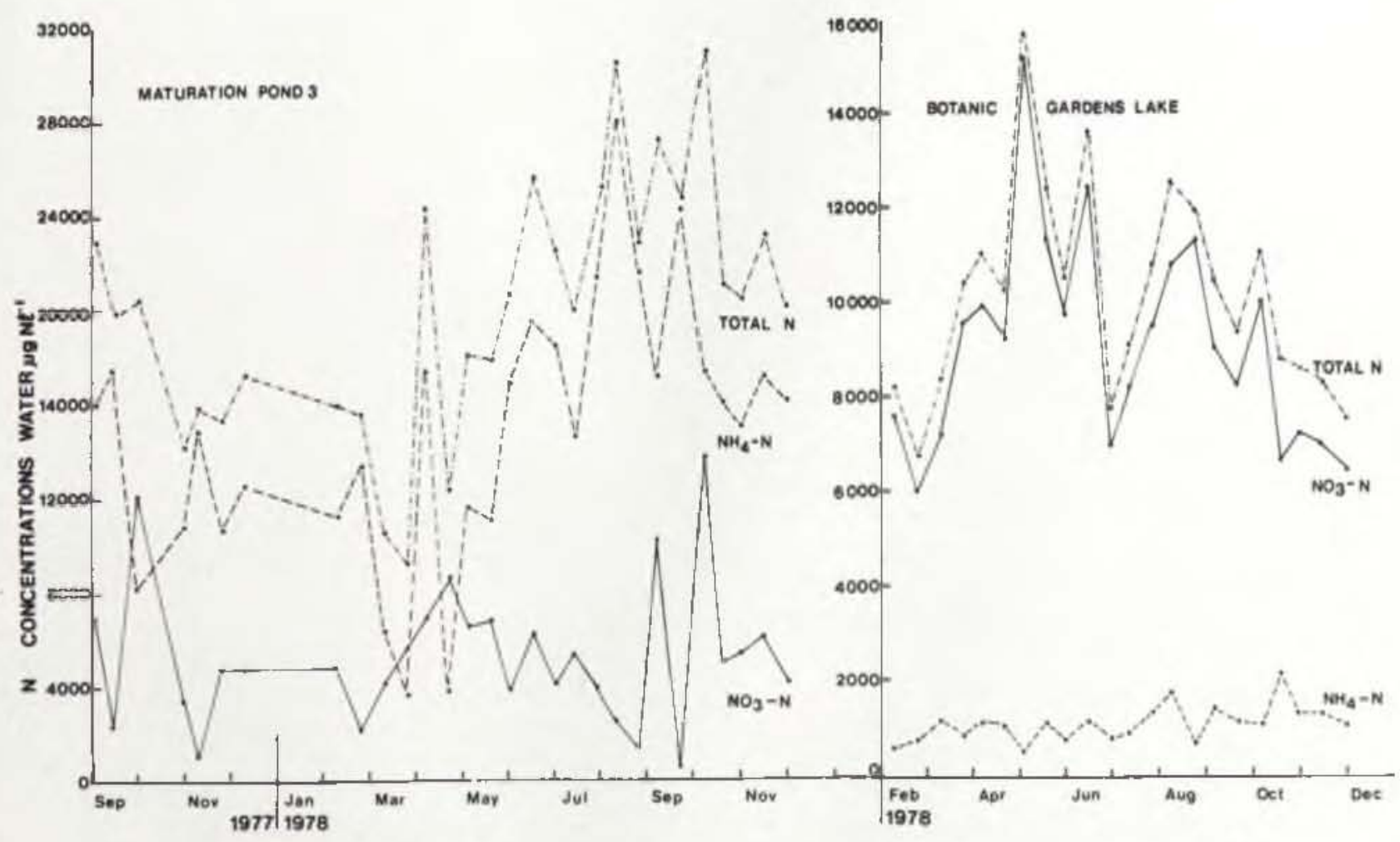

FIG. 5. - Nitrogen ( $\mathrm{NO}_{3}-\mathrm{N}, \mathrm{NH}_{4}-\mathrm{N}$ and total $\mathrm{N}$ ) concentrations in the water, averaged over each growing interval, beneath loosely crowded populations enclosed at two field sites. 


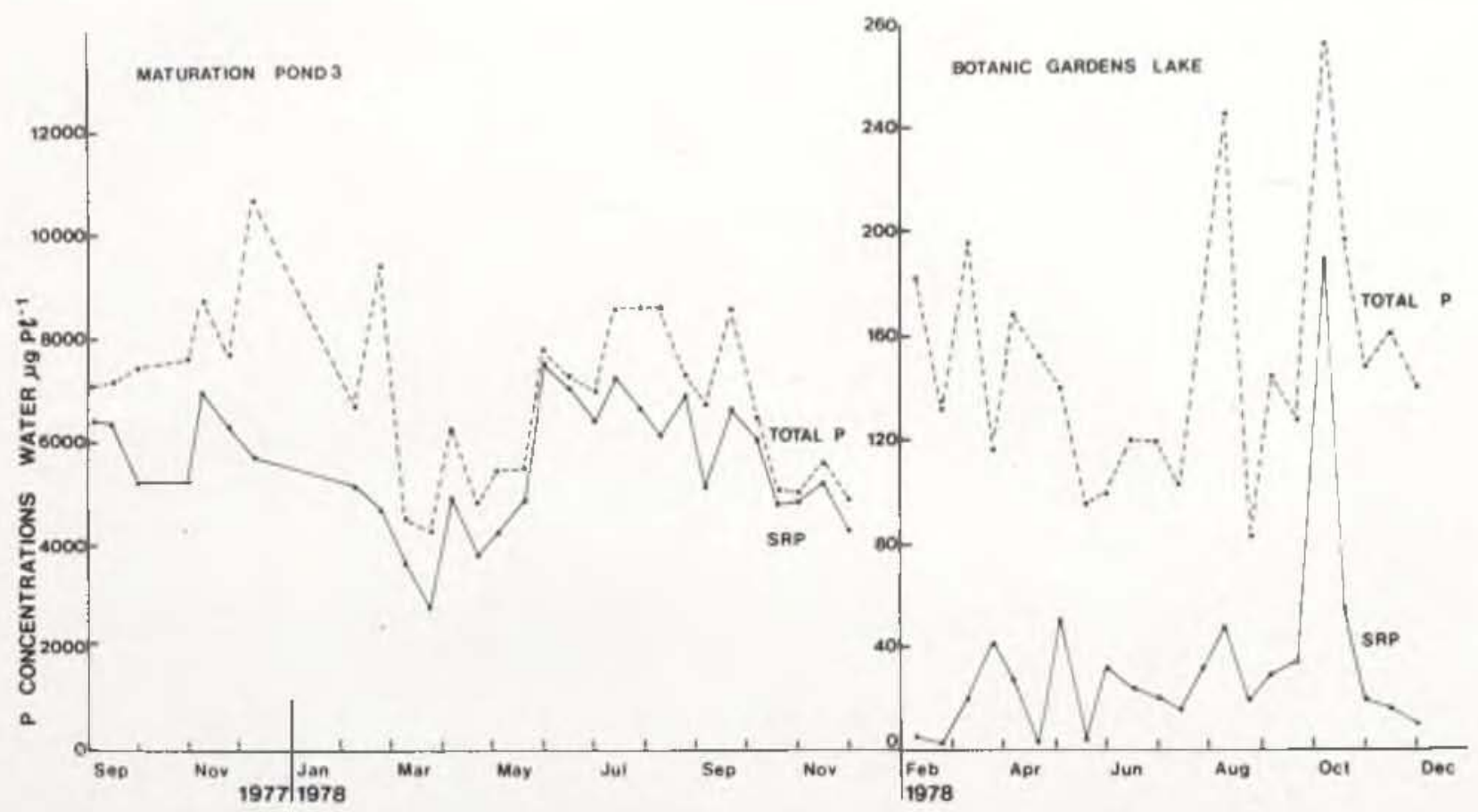

FIG. 6. - Phosphorus (SRP and total P) concentrations in the water, averaged over each growing interval, beneath loosely crowded populations enclosed at two field sitcs.

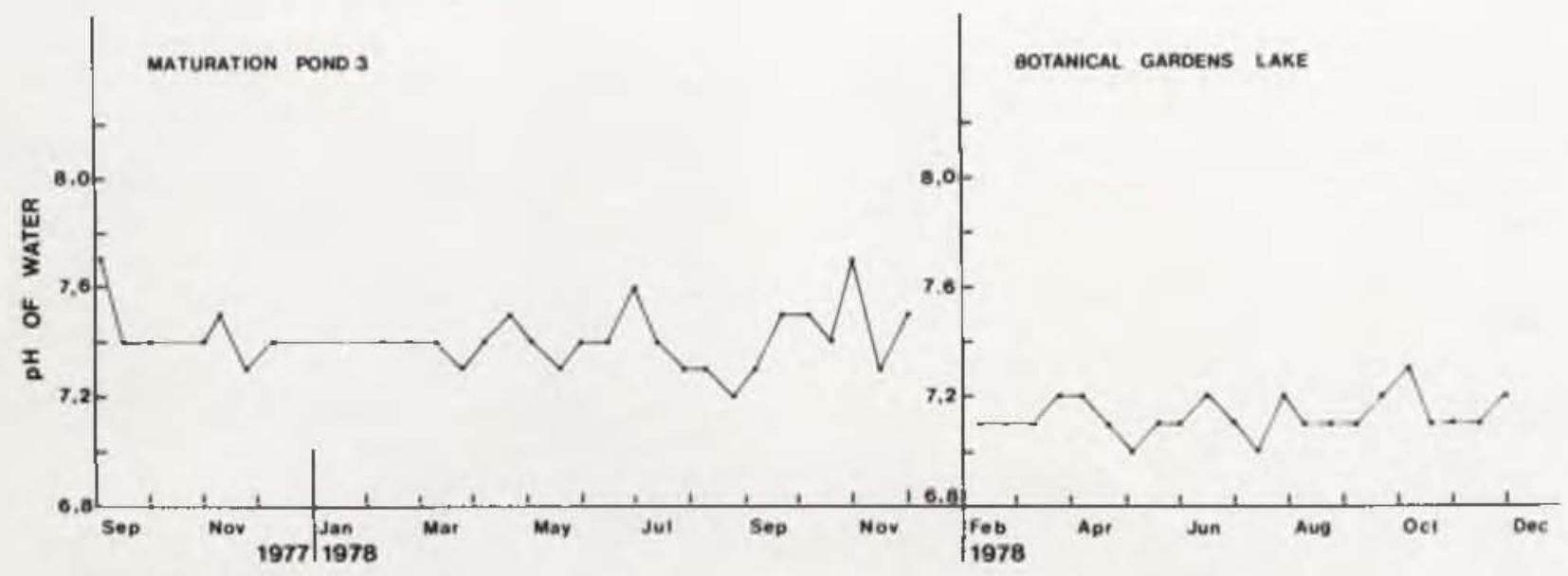

FIG. 7. - The variation in water $\mathrm{pH}$, as daily averages over each growing interval, beneath loosely crowded populations enclosed at two field sites.

trations in the water were much higher. The latter was attributed partly to enrichment by fertilizer runoff and to a higher rate of nitrification at the BGL site (Musil, 1982). There were no differences in the $\mathrm{N}$ and $\mathrm{P}$ concentrations in the water beneath the loosely and densely crowded populations enclosed at the MP3 site (Musil, 1982).

At both sites, the water $\mathrm{pH}$ values were in close proximity to $\mathrm{pH} 7,0$. Only minor variations in the water $\mathrm{pH}(\mathrm{pH} \mathrm{7,0}$ to 7,3 and $\mathrm{pH} \mathrm{7,2} \mathrm{to} \mathrm{7,7} \mathrm{at} \mathrm{the}$ $\mathrm{BGL}$ and MP3 sites respectively) occurred at these two sites during the year. There were no differences in the water pH beneath the loosely and densely crowded populations enclosed at the MP3 site (Musil, 1982).

\section{Specific growth rates}

Specific growth rates of marginal and central forms, growing in loosely and densely crowded populations respectively, at the two sites are illustrated in Fig. 8.

At both sites, specific growth rates of marginal forms followed a distinct seasonal pattern with values decreasing progressively after summer (September to March) through to winter (May to August). During 1978, the highest specific growth rates, 0,1698 and $0,1227 \mathrm{~g}$ fresh mass $\mathrm{g}^{-1} \mathrm{~d}^{-1}(16,98$ and $12,27 \% \mathrm{~d}^{-1}$ at the MP3 and BGL sites respectively, were measured during summer, in February, with the lowest specific growth rates, 0,0526 and $0,0305 \mathrm{~g}$ 


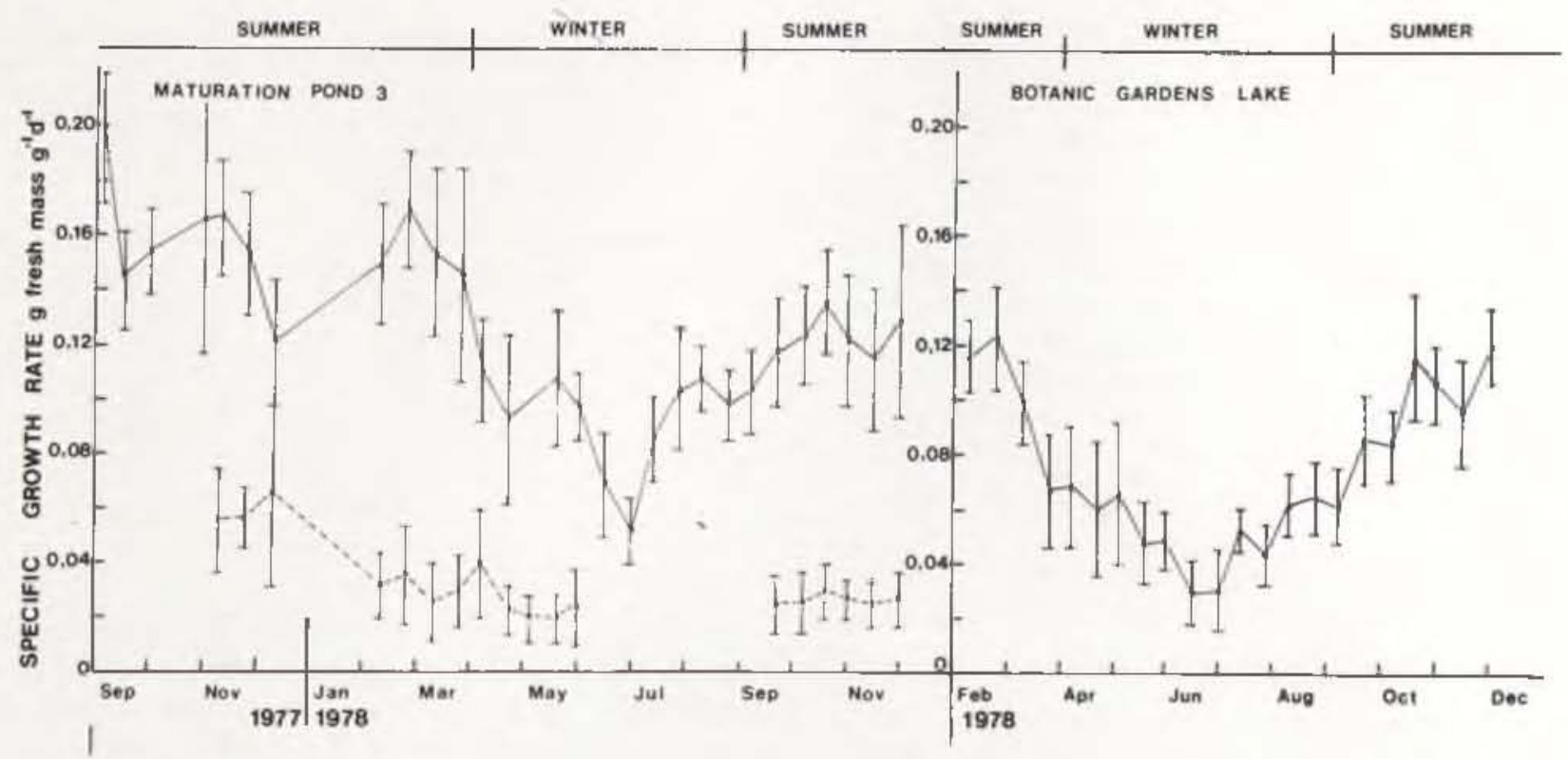

FIG. 8. - Specific growth rates of E. crassipes over each growing interval, at two field sites. Solid line $=$ marginal forms growing in loosely crowded populations (means of 40 replicates). Broken line $=$ central forms, growing in densely crowded populations (means of 30 replicates). No plants of the central form were produced during June, July and August. Standard deviations of measured specific growth rates are shown by bars.

fresh mass $g^{-1} d^{-1}\left(5,26\right.$ and $\left.3,05 \% d^{-1}\right)$ at these two sites respectively, being measured for marginal forms during midwinter, in June. Throughout 1978, specific growth rates of marginal forms at the MP3 site were significantly higher $(P \leqslant 0,01)$, than those at the BGL sitc (Musil, 1982) and reflected the higher total $\mathrm{N}$ and total $\mathrm{P}$ concentrations in the water at the MP3 site (Figs 5 \& 6). In general, specific growth rates of marginal forms at both sites fell in the range of specific growth rates $\left(3,0\right.$ to $\left.12,5 \% \mathrm{~d}^{-1}\right)$ reported by various authors (Seaman \& Porterfield, 1964; Bock, 1969; Knipling et al., 1970; Morris, 1974; Boyd, 1976) for E. crassipes growing under subtropical to tropical climates in other parts of the world.

In contrast to marginal forms, specific growth rates of central forms at the MP3 site did not show any distinct seasonal pattern, since no plants of the central growth form were produced during the midwinter months of June, July and August. The highest

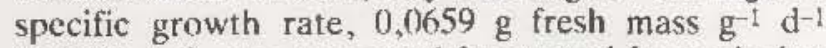
$\left(6,59 \% \mathrm{~d}^{-1}\right)$, was measured for central forms during summer, in December, 1977, with the lowest specific

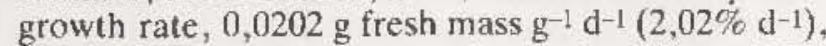
being measured during winter, in May, 1978. Throughout 1977 and 1978, specific growth rates of central forms at the MP3 site were significantly lower ( 17 to $35 \%, P \leqslant 0,001)$ than those of marginal forms (Musil, 1982).

The significantly lower specific growth rates measured in densely crowded ficld populations may be partly related to the adverse effects of self shading and intraspecific competition arising through overcrowding in such populations, as well as to the intrinsic morphological limitations of plants of the central form occurring in such populations. Center \& Spencer (1981) have shown that the production of $E$. crassipes plants with elongate petioles (central forms) results in a decline in the lamina area ratio (LAR), i.e. in relatively less photosynthetic area per unit of plant weight. The ratio of the lamina area to plant weight is similar to the leaf area ratio of other authors (e.g. Beevers \& Cooper, 1964; Radford, 1967). Consequently, if it is assumed that photosynthesis is proportional to the lamina arca and respiration to weight, the LAR should be an index of the $P / R$ ratio and an indicator of the growth potential, i.e. net photosynthesis. Under these assumptions, central forms with elongate petioles should have the smallest potential for growth and consequently the lowest specific growth rate.

\section{Testing the model}

\section{Identifying the limiting nutrient}

At each site, the nutrient limiting $E$. crassipes growth rate was estimated from the average total $\mathrm{N}$ and total $\mathrm{P}$ concentrations in the water using the mean half saturation (Ks) concentrations of $976 \mu \mathrm{g}$ $\mathrm{N} \ell^{-1}$ and $94,1 \mu \mathrm{g} P \ell^{-1}$, derived under culture conditions of $\mathrm{N}$ and $\mathrm{P}$ limitation (Musil \& Breen 1985), in the Monod model. For example, the average total $\mathrm{N}$ and total $\mathrm{P}$ concentrations determined in the water at the MP3 site during 1978 were $20746 \mu \mathrm{g}$ $N \ell^{-1}$ and $6569 \mu \mathrm{g} \mathrm{P} \ell^{-1}$ (Musil, 1982). The percentage of the maximum specific growth rate (Umax) that E. crassipes would achieve at (i) the average total $N$, (ii) the average total $P$ concentrations in the water at this site were estimated using the Monod model as follows:

$$
\begin{aligned}
\mathrm{U} & =\mathrm{U} \max \frac{20746}{976+20746} \times 100 \ldots \ldots \text { (i) } \\
& =95,5 \% \mathrm{U} \max \\
\mathrm{U} & =\mathrm{U} \max \frac{6569}{94,1+6569} \times 100 \ldots \ldots \text { (ii) } \\
& =98,6 \% \mathrm{U} \max
\end{aligned}
$$


The results show that at the MP3 site $E$. crassipes would achieve a lower percentage of the Umax at the average total $\mathrm{N}$ than at the average total $\mathrm{P}$ concentrations in the water which indicates that $\mathrm{N}$ was the limiting nutrient.

At the BGL site, on the other hand, the average total $\mathrm{N}$ and total $\mathrm{P}$ concentrations determined in the water during 1978 were $10206 \mu \mathrm{g} \mathrm{N} \ell^{-1}$ and $150 \mu \mathrm{g}$ $P \ell^{-1}$ (Musil, 1982). Using the Monod model, it was estimated that $E$. crassipes would achieve $91,3 \%$ and $61,4 \%$ of the Umax at the average total $N$ and total $P$ concentrations in the water respectively at this site, indicating that $\mathbf{P}$ was the limiting nutrient.

\section{Predicting Umax for different temperatures}

The Umax values derived for $E$. crassipes under culture conditions of $\mathrm{N}$ and $\mathrm{P}$ limitation, at mean daily air temperatures of $24^{\circ} \mathrm{C}$ and $28^{\circ} \mathrm{C}$ respectively, were $0,0886 \mathrm{~g}$ fresh mass $\mathrm{g}^{-1} \mathrm{~d}^{-1}$ for $\mathrm{N}$ and $0,1089 \mathrm{~g}$ fresh mass $\mathrm{g}^{-1} \mathrm{~d}^{-1}$ for $\mathrm{P}$ (Musil \& Breen, 1985). Using these values, the Umax of $E$. crassipes, under conditions of $\mathrm{N}$ or P limitation, may be predicted for other temperatures according to the Van't Hoff rule (Tables 1 \& 2) from the Arrhenius equations for the exponential relationships between $U \max (n)$ and $U \max (p)$ and temperature. Assuming a $Q_{10}$ of 2,0 , these relationships are:

$$
\operatorname{Umax}(n)=3,9151 \times 10^{7} \ell^{-5916 / \mathrm{T}}
$$

where $\operatorname{Umax}(n)=$ maximum specific growth rate for $\mathrm{N}$ ( $\mathrm{g}$ fresh mass $\left.\mathrm{g}^{-1} \mathrm{~d}^{-1}\right) ; \mathrm{T}=$ absolute mean daily air temperature $\left({ }^{\circ} \mathrm{K}\right)$.

$$
U \max (p)=6,5292 \times 10^{7} e^{-6088 / T}
$$

where Umax $(p)=$ maximum specific growth rate for $P\left(g\right.$ fresh mass $\left.g^{-1} d^{-1}\right) ; T=$ absolute mean daily air temperature $\left({ }^{\circ} \mathrm{K}\right)$.

\section{Comparison of predicted and measured specific growth rates}

Incorporating these equations and the $\mathrm{Ks}$ concentrations of $976 \mu \mathrm{g} \mathrm{N} \ell^{-1}$ and $94,1 \mu \mathrm{g} \mathrm{P} \ell^{-1}$ into the Monod model, specific growth rates were predicted for $E$. crassipes, over each growing interval at the MP3 and BGL sites, from the limiting $\mathrm{N}$ or $\mathrm{P}$ concentrations in the water and mean daily air temperatures. These were then compared with measured

TABLF 1.-Maximum specific growth rates (Umax) predicted for $E$. crassipes for various temperatures according to the van't Hoff rule. Predictions were based on the Umax value of $0,0886 \mathrm{~g}$ fresh mass $\mathrm{g}^{-1} \mathrm{~d}^{-1}$, derived under culture conditions of $\mathrm{N}$ limitation at a mean daily air temperature of $24^{\circ} \mathrm{C}$ (Musit \& Breen, 1985 )

\begin{tabular}{ccc}
\hline Mean daily temperature & $1 / \mathrm{T} \times 10^{4}$ & $\begin{array}{c}\text { Umax } \\
{ }^{\circ} \mathrm{C}\end{array}$ \\
\hline 24 & 33,6473 & 0,0886 \\
\hline 21 & 33,9904 & 0,0723 \\
19 & 34,2231 & 0,0630 \\
17 & 34,4589 & 0,0548 \\
14 & 34,8189 & 0,0443 \\
\hline
\end{tabular}

TABLF 2.-Maximum specific growth rates (Umax) predicted for $E$. crassipes for various temperatures according to the $v_{a n}{ }^{\prime} t$ Hoff rule, Predictions were based on the L'max value of $0,1089 \mathrm{~g}$ fresh mass $\mathrm{g}^{-1} \mathrm{~d}^{-1}$, derived under culture con. ditions of $\mathrm{P}$ limitation at a mean daily air temperature of $28^{\circ} \mathrm{C}$ (Musil \& Breen, 1985 )

\begin{tabular}{ccc}
\hline Mean daily temperature & $1 / \mathrm{T} \times 10^{4}$ & $\begin{array}{c}\text { Umax } \\
{ }^{0} \mathrm{C}\end{array}$ \\
\hline 28 & 33,2005 & 0,1089 \\
25 & 33,5345 & 0,0889 \\
23 & 33,7609 & 0,0774 \\
21 & 33,9904 & 0,0673 \\
18 & 33,3406 & 0,0544 \\
\hline
\end{tabular}

specific growth rates. At the MP3 site, where $\mathrm{N}$ was estimated to be the limiting nutrient, specific growth rates were predicted from the various $\mathrm{N}\left(\mathrm{NO}_{3}-\mathrm{N}\right.$, $\mathrm{NH}_{4}-\mathrm{N}$ and total $\mathrm{N}$ ) fractions in the water using Equation 1 in the Monod model. At the BGL site, where $\mathrm{P}$ was estimated to be the limiting nutrient, specific growth rates were predicted from the various P (SRP and total P) fractions in the water using Equation 2 in the Monod model. For example, the mean daily air temperature and total $\mathrm{N}$ concentration in the water at the MP3 site over the growing interval $1 / 2$ to $16 / 2 / 78$ were $24,9^{\circ} \mathrm{C}$ and $15970 \mu \mathrm{g}$ $\mathrm{N} \ell^{-1}$ respectively (Musil, 1982). The specific growth rate (U) was predicted for $E$. crassipes for this set of conditions as follows:

$$
\mathrm{U}=3,9151 \times 10^{7} e^{-5916 / 24,9+273,2} \times \frac{15970}{976+15970}
$$

$$
=0,0887 \mathrm{~g}_{\text {fresh }} \text { mass } \mathrm{g}^{-1} \mathrm{~d}^{-1}\left(8,87 \% \mathrm{~d}^{-1}\right) \text {. }
$$

Predicted specific growth rates and those measured for marginal and central forms, growing in loosely and densely crowded populations respectively, at the two sites are illustrated in Figs 9 and 10.

At the MP3 site, specific growth rates predicted from total $\mathrm{N}, \mathrm{NH}_{4}-\mathrm{N}$ and to a lesser extent from $\mathrm{NO}_{3}-\mathrm{N}$ concentrations in the water followed a fairly similar seasonal pattern to those measured for marginal forms with values decreasing progressively after summer (September to March) through to winter (May to August). A similar relationship between measured specific growth rates and those predicted from total $P$ concentrations in the water was obtained at the BGL site. Specific growth rates predicted from SRP concentrations in the water at the BGL site, however, were extremely variable and did not follow any recognizable seasonal pattern.

In general, specific growth rates predicted from the various $\mathrm{N}$ or $\mathrm{P}$ fractions in the water at the two sites were significantly lower than those measured for marginal forms. For example, of the 29 specific growth rates predicted from total $\mathrm{N}$ concentrations in the water at the MP3 site, only 3 (during April and June) fell within the standard deviations of measured values. Of the 22 specific growth rates predicted from total $P$ concentrations in the water at the BGL site, only 6 (during March, April, June and 


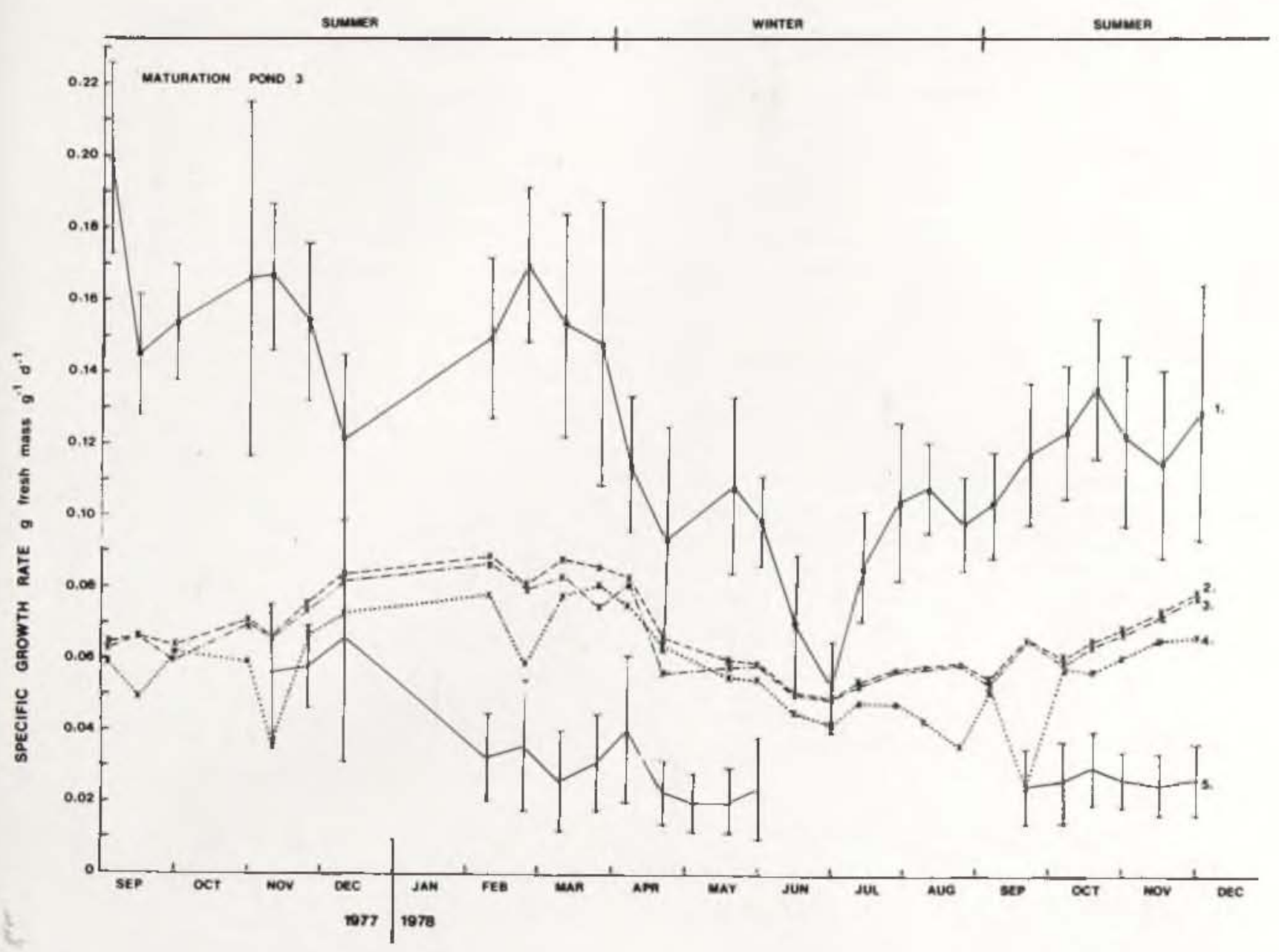

FIG. 9. - Specific growth rates predicted for $E$. crassipes from 2, total $\mathrm{N} ; 3, \mathrm{NH}_{4}-\mathrm{N}$ and $4, \mathrm{NO}_{3}-\mathrm{N}$ concentrations in the water, over each growing interval, at the maturation pond 3 site compared with those measured for 1 , marginal forms, growing in loosely crowded populations and 5, central forms, growing in densely crowded populations. Standard deviations of measured specific growth rates are shown by bars. Umax values used in the Monod model derived under culture conditions of $\mathrm{N}$ limitation and expressed as a function of air temperature.

July) fell within the standard deviations of measured values. The differences between measured specific growth rates and those predicted from other $\mathrm{N}$ $\left(\mathrm{NH}_{4}-\mathrm{N}\right.$ and $\mathrm{NO}_{3}-\mathrm{N}$ ) or $\mathrm{P}$ (SRP) fractions in the water at the two sites, however, were generally larger than the differences between measured specific growth rates and those predicted from total $\mathrm{N}$ or total $P$ concentrations in the water. This suggests that specific growth rates of $E$. crassipes in the field may be more accurately predicted from total $\mathrm{N}$ or total $\mathbf{P}$ concentrations, than from other $\mathbf{N}$ or $\mathbf{P}$ fractions, in the water. At both sites, the smallest differences between measured specific growth rates and those predicted from total $\mathrm{N}$ or total $\mathrm{P}$ concentrations in the water occurred during midwinter in June when relative humidities and diffuse radiant fluxes were at their lowest levels (Figs $3 \& 4$ ). These results suggest that the Umax values derived for $E$. crassipes, under culture conditions of $\mathrm{N}$ and $\mathrm{P}$ limitation (Musil \& Breen, 1985), may have been depressed by lowered relative humidities and radiant flux densities in the greenhouse, since specific growth rates predicted from total $\mathrm{N}$ or total $\mathrm{P}$ concentrations in the water at the two sites were significantly lower than those measured for marginal forms, except when diffuse radiant fluxes and relative humidities in the field were low.
Relative humidities recorded in the greenhouse during the experimental determination of kinetic coefficients for $E$. crassipes (Musil \& Breen, 1985) were lower than those recorded during summer for the two field sites in the Durban area (Fig. 3). Mean daily relative humidities in the greenhouse ranged from 61 to $67 \%$, whereas those recorded during summer for the two field sites ranged from 74 to $85 \%$. Since Freidel et al. (1978) have shown that $E$. crassipes growth rate decreases with a decrease in relative humidity, it would appear that the Umax values derived for $E$. crassipes in culture were depressed by lower relative humidities in the greenhouse. In addition, it is possible that radiant flux densities in the greenhouse limited $E$. crassipes growth rate during the experimental determination of kinetic coefficients for this plant. Measurements of light intensity at midday in full sunlight inside and outside the greenhouse showed that light intensity in the greenhouse was attenuated by ca $37 \%$ (Musil. 1982).

No correction factor could be incorporated into the model to amend the Umax values derived for $E$. crassipes under lowered relative humidities and radiant flux densities in the greenhouse, since the ratios between measured and predicted specific growth 


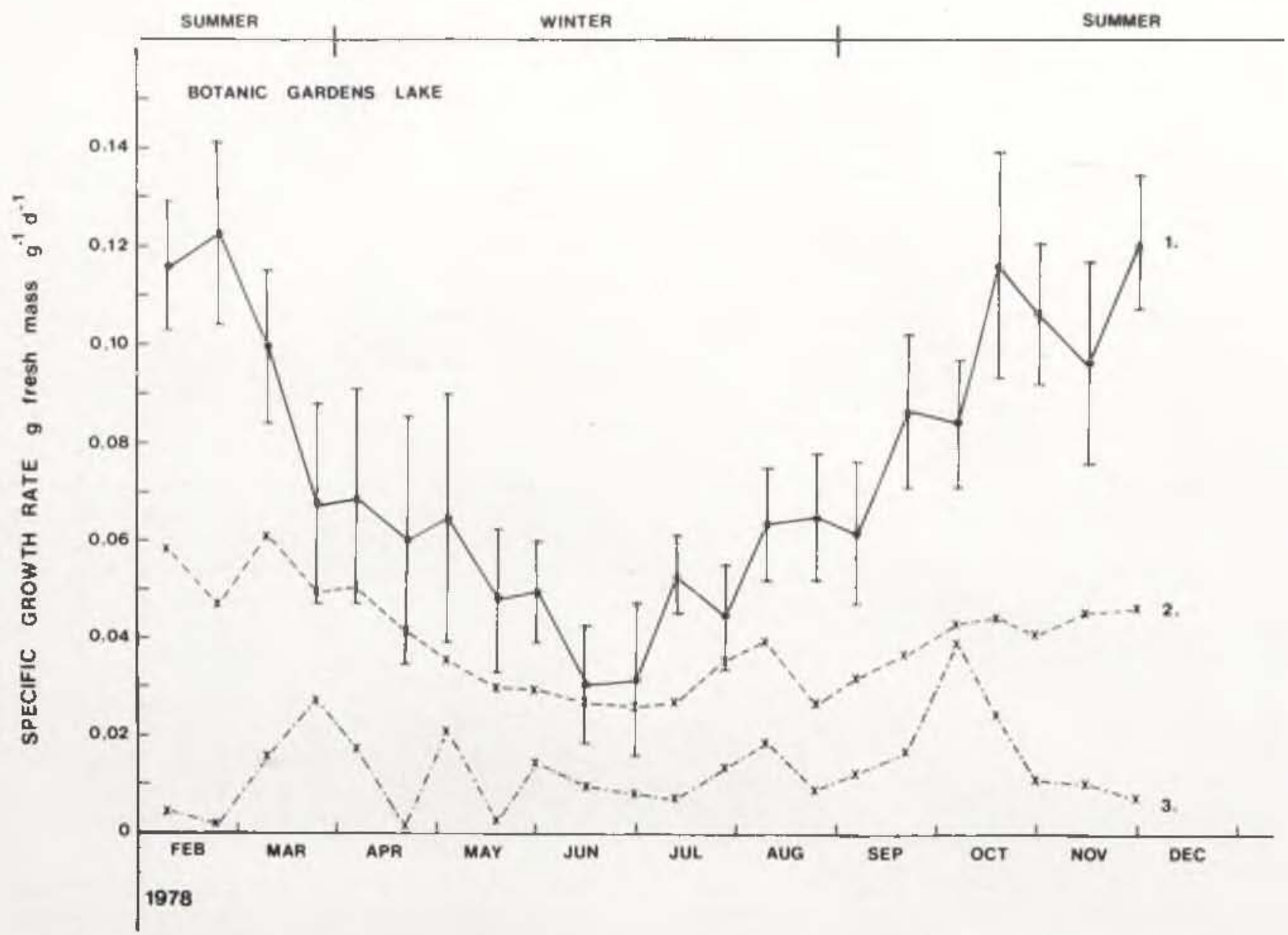

FIG. 10. - Specific growth rates predicted for $E$. crassipes from 2, total $\mathbf{P}$ and 3, SRP concentrations in the water, over each growing interval, at the Botanic Gardens Lake site compared with those measured for 1 , marginal forms, growing in loosely crowded populations. Standard devjations of measured specific growth rates are shown by bars. Umax values used in the Monod model derived under culture conditions of $\mathrm{P}$ limitation and expressed as a function of air temperature.

rates varied considerably during the year. For example, at the MP3 site the ratios between specific growth rates measured for marginal forms and those predicted from total $\mathrm{N}$ concentrations in the water ranged from ca 2,5 during summer to ca 1,1 during winter. Similarly, at the BGL sitc, the ratios between measured specific growth rates and those predicted from total $P$ concentrations in the water ranged from ca 2,6 during summer to ca 1,1 during winter.

In contrast to specific growth rates of marginal forms, those of central forms growing in densely crowded populations at the MP3 site were often significantly lower than those predicted from the various $\mathrm{N}$ fractions in the water (Fig. 9). For example, only 2 of the 18 specific growth rates predicted from total $\mathrm{N}$ concentrations in the water at this site fell within the standard deviations of measured values. No significance, however, was attached to the observation that the differences between specific growth rates measured for central forms and those predicted from total $\mathrm{N}$ concentrations in the water were slightly larger than the differences between meas. ured specific growth rates and those predicted from other $\mathrm{N}\left(\mathrm{NH}_{4}-\mathrm{N}\right.$ and $\left.\mathrm{NO}_{3}-\mathrm{N}\right)$ fractions in the water. The poor affinity obtained between predicted specific growth rates and those measured for centra! forms may be attributed to the specific growth rate of E. crassipes being depressed by intraspecific competition and self shading in densely crowded field populations. This suggests that, unless a correction factor is introduced into the model to amend the Umax for the density of the plant population, Umax values derived for plants of the marginal growth form in culture cannot be used in the Monod model to predict specific growth rates of central forms growing in densely crowded field populations.

Although Umax values derived for $E$. crassipes under culture conditions of $\mathbf{N}$ and $\mathbf{P}$ limitation were of little value in the Monod model for accurately predicting specific growth rates of plants growing in loosely or densely crowded field populations, it is possible that more reliable estimates of Umax may be derived for $E$. crassipes from the field data. At the MP3 site, where $\mathrm{N}$ and $\mathrm{P}$ concentrations in the water were very high, it was estimated from the mean Ks concentrations, derived under culture conditions of $\mathrm{N}$ and $\mathrm{P}$ limitation, that $E$. crassipes would achieve ca 95,5 and $98,6 \%$ of its Umax at the average total $\mathrm{N}$ and total $\mathrm{P}$ concentrations in the water respectively. It is evident, therefore, that, even though $\mathrm{N}$ was considered to be the limiting nutrient at this site, $\mathbf{N}$ and $\mathbf{P}$ concentrations in the water approached those saturating to $E$. crassipes growth rate. Consequently, if it is assumed that specific growth rates measured for plants of the marginal and 
central forms at specific temperatures at the MP3 site closely approximate their respective Umax values, it should be possible to express the relationships, if exponential, between these estimated Umax values of marginal and central forms and air temperatures in the form of Arrhenius equations. These equations can then be incorporated into the Monod model to predict specific growth rates of marginal and central forms, from the limiting $\mathrm{N}$ or $\mathrm{P}$ concentrations in the water and mean daily air temperatures, at other field sites. This should improve the model's accuracy of prediction for plants growing in both loosely and densely crowded field populations. The mean $\mathrm{Ks}$ concentrations derived for $E$. crassipes under culture conditions of $\mathrm{N}$ and $\mathrm{P}$ limitation, on the other hand, appear fairly reliable, since predicted specific growth rates generally followed a similar seasonal pattern to those measured.

\section{Refining the model}

\section{Deriving Umax in the field}

Arrhenius plots of specific growth rates (estimated Umax values) of marginal and central forms, expressed as natural logarithms ( $\left.\log _{e}\right)$, against the reciprocals of absolute mean daily air temperatures at the MP3 site (Figs $11 \& 12$ ), over the period February to December, 1978 , yielded linear relationships with the correlation coefficients being high and significant at $P \leqslant 0,01$.

The regression equation exponentially relating specific growth rates (estimated Umax values) of marginal forms at the MP3 site to the reciprocals of absolute mean daily air temperatures was:

$$
\mathrm{U}=5,2631 \times 10^{8} e^{-6540 \pi} \mathrm{T} .
$$

where $U=$ specific growth rate (estimated maximum specific growth rate) $\mathrm{g}$ fresh mass $\mathrm{g}^{-1} \mathrm{~d}^{-1}$; $\mathrm{T}=$ absolute mean daily temperature ${ }^{\circ} \mathrm{K}$.

$A Q_{10}$ value of 2,14 , in the temperature range 15 to $25^{\circ} \mathrm{C}$, was calculated from the above expression. This compares favourably with the $\mathrm{Q}_{10}$ value of 2,12 reported by Goldman (1972) for the exponential relationship between the Umax values of various species of fresh water algae and temperature, in the range 19 to $39^{\circ} \mathrm{C}$. It demonstrates that the effect of air temperature on the Umax of E. crassipes (marginal forms) follows the Van't Hoff rule and confirms the initial hypothesis made. In addition, the activation energy of 12,978 calories mole-1 calculated for marginal forms from the above expression compares favourably with the activation energy of 13,356 calories mole-1 reported by Goldman (1972) for algae.

The regression equation exponentially relating specific growth rates (estimated Umax values) of central forms at the MP3 site to the reciprocals of absolute mean daily air temperatures was:

$$
\mathrm{U}=1,9932 \times 105 e^{-4661 / \mathrm{T}}
$$
4

where $U=$ specific growth rate (estimated maximum specific growth rate) $\mathrm{g}$ fresh mass $\mathrm{g}^{-1} \mathrm{~d}^{-1} ; \mathrm{T}=$ absolute mean daily air temperature ${ }^{\circ} \mathrm{K}$.

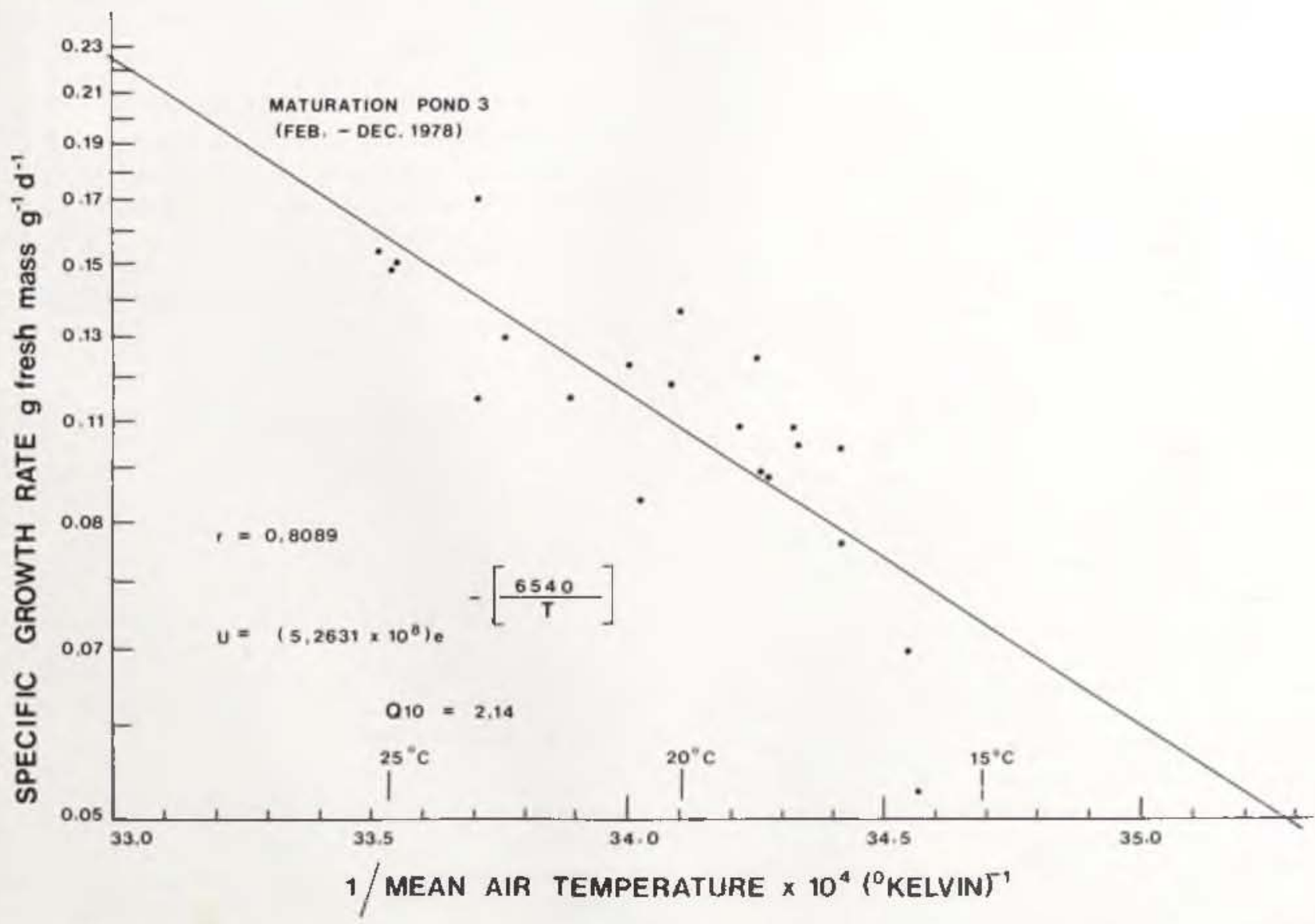

FIG. 11. - An Arrhenius plot of specific growth rates (estimated Umax values) of marginal forms ( $\log _{\mathrm{g}}$ ) against the reciprocals of absolute mean daily air temperatures at the maturation pond 3 site. 


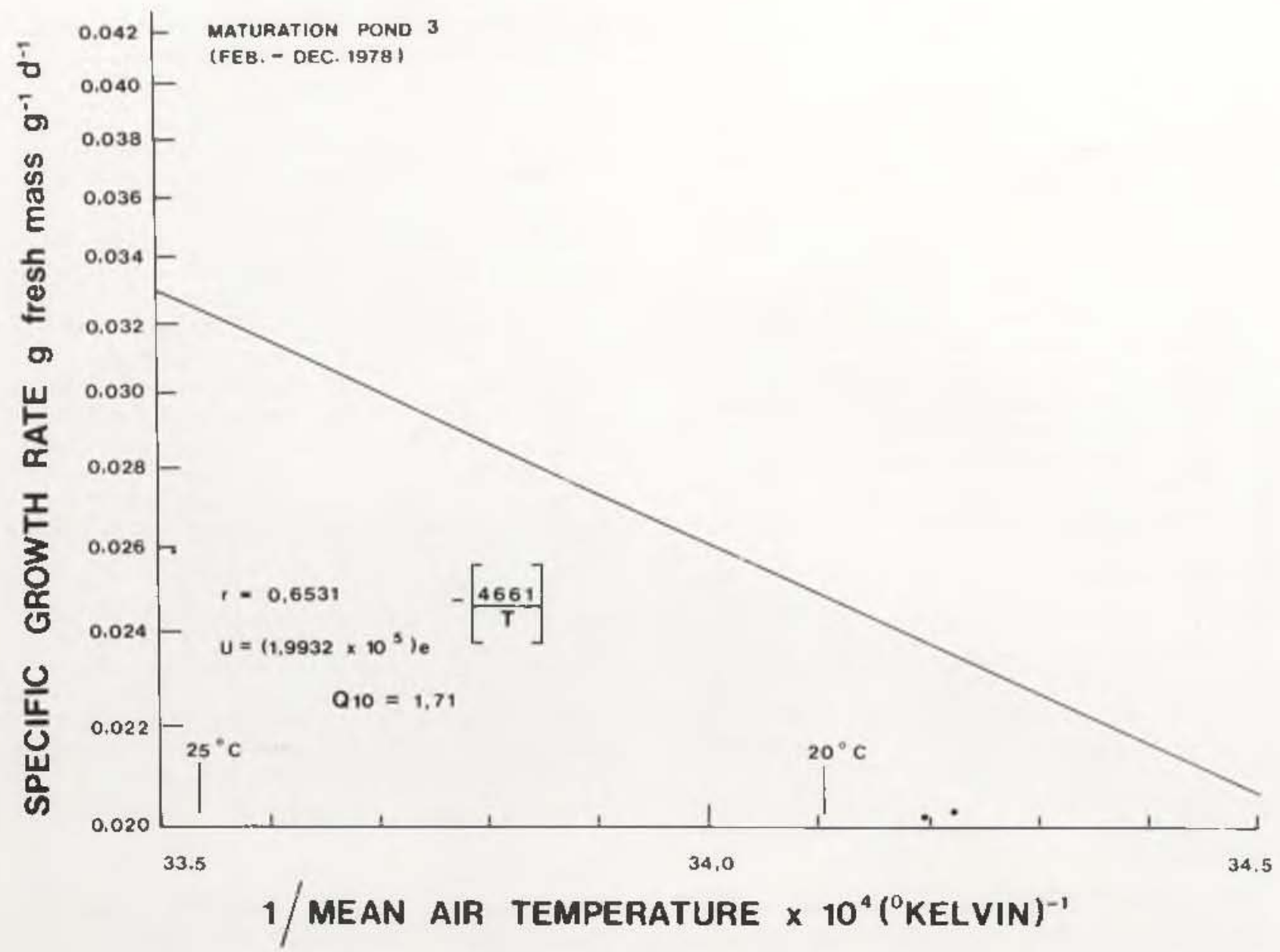

FIG. 12. - An Arrhenius plot of specific growth rates (estimated Umax values) of central forms (Log, against the reciprocals of absolute mean daily air temperatures at the maturation pond 3 site.

$A Q_{10}$ value of only 1,71 in the temperature range 15 to $25^{\circ} \mathrm{C}$, was calculated from the above expression. This demonstrates that central forms growing in densely crowded field populations show a proportionally smaller increase in their specific growth rate (estimated Umax) with a $10^{\circ} \mathrm{C}$ rise in the mean daily air temperature than do marginal forms growing in loosely crowded field populations. The lower $Q_{10}$ value obtained for central forms was attributed to their specific growth rate being depressed in densely crowded field populations.

With respect to the above exponential expressions, it shouid be pointed out, however, that recent investigations have shown that plant growth in the field can respond linearly rather than exponentially to environmental temperature, which suggests that the asymetric bell-shaped response to temperature may not be as widely applicable as was formerly considered. Gallagher \& Biscoe (1979), for example, have demonstrated that, in the absence of water stress, the expansion rate of barley leaves is directly proportional to the temperature of the stem apex. It remains to be seen, however, what the theoretical interpretation of such linear responses can be.

\section{Comparison of predicted and measured specific} growth rates

The usefulness of Equation 4 in the Monod model could not be assessed, since no measurements of specific growth rates of central forms were obtained at the BGL site.

Substituting Equation 3 for Equation 1 in the Monod model, specific growth rates were repredicted for marginal forms at the BGL site from the limiting P (SRP and total P) concentrations in the water and mean daily air temperatures. Predicted specific growth rates and those measured for marginal forms are illustrated in Fig. 13.

Of the 22 specific growth rates predicted from total $\mathrm{P}$ concentrations in the water at the BGL site, 14 (ca $64 \%$ ) fell within the standard deviations of measured specific growth rates. Predicted specific growth rates generally followed the same seasonal pattern as measured specific growth rates with values decreasing progressively after summer (September to March) through to winter (May to August). Bell (1981) pointed out that, by analogy with the correlation coefficient $(r)$, a coefficient of variation $\left(R^{2}\right)$ may be computed to test model outputs compared with data defined as:

$$
R^{2}=1-\frac{\text { sum of squares of residuals }}{n S^{2} y}
$$

where $\mathrm{n}$ is the number of data points and $\mathrm{SD}^{2} \mathrm{y}$ is the variance in predicted values. For values of $\mathrm{R}^{2}$ that are high and approximate to 1, the fit is good; for values of $\mathbf{R}^{2}$ that are low and approximate to 0 , the 
fit is poor. For values of $\mathrm{R}^{2}$ that are inbetween and approximate to 0,5 , the situation is uncertain. Dent \& Blackie (1979) recommended a simple regression analysis between model outputs and data as paired observations which produces the same value of $R^{2}$ as defined. The coefficient of variation $\left(R^{2}\right)$ calculated between measured specific growth rates and those predicted from total $\mathrm{P}$ concentrations in the water at the $\mathrm{BGL}$ site had a value of $\mathrm{R}^{2}=0,5321$. Consequently, the observed affinity between predicted and measured values could not be regarded as significant over the entire growing season. Specific growth rates predicted from SRP concentrations in the water at this site were extremely variable and did not follow any recognizable scasonal pattern. Only one of the predicted values fell within the standard deviations of measured values.

The differences between measured specific growth rates and those predicted from total $P$ concentrations in the water at the BGL site were considerably smaller than the differences between measured specific growth rates and those predicted from other $P$ (SRP) fractions in the water (Fig. 13), Similar results were obtained at sites where $N$ was estimated to be the limiting nutrient (Musil, 1982). These results indicate that specific growth rates of $E$. crassipes in the field are more accurately predicted from the limiting total $\mathrm{N}$ or total $\mathrm{P}$ concentrations, than from other $\mathbf{N}$ or $\mathbf{P}$ fractions, in the water which suggests that the plant may utilize both inorganic and organic forms of $\mathbf{N}$ and $\mathbf{P}$ for growth.

With respect to P, Jeschke \& Simonis (1965) reported that the main source of $P$ for growth of aquatic plants is in the form of inorganic phosphates. However, specific growth rates of marginal forms at the BGL site were more accurately predicted from total P than from SRP concentrations in the water. Conscquently, it would appear that total $\mathrm{P}$ concentrations in the water at this site better reflected the total amount of $\mathrm{P}$ available to plants during growth, some of the P for growth of plants possibly being provided by release of that bound to sediments as well as to other soluble and insoluble fractions in the water. For example, when $P$ is added to lakes, it is rapidly removed from solution by adsorption onto sediments (Hepher, 1958; Hayes \& Phillips, 1968). This $P$ is not rendered entirely unavailable since sediment $\mathrm{P}$ and dissolved $\mathrm{P}$ exist in equilibrium ( $\mathrm{He}$ pher, 1958; Pomeroy et al., 1965). The equilibrium concentration increases with increased $P$ content in the sediment (Pomeroy et al., 1965). Consequently, removal of $\mathrm{P}$ from the water by $E$. crassipes during growth would displace the $P$ equilibrium allowing additional $\mathrm{P}$ to be released from the sediments into the overlying water. Alternatively, it has been shown that many zooplankton and phytoplankton

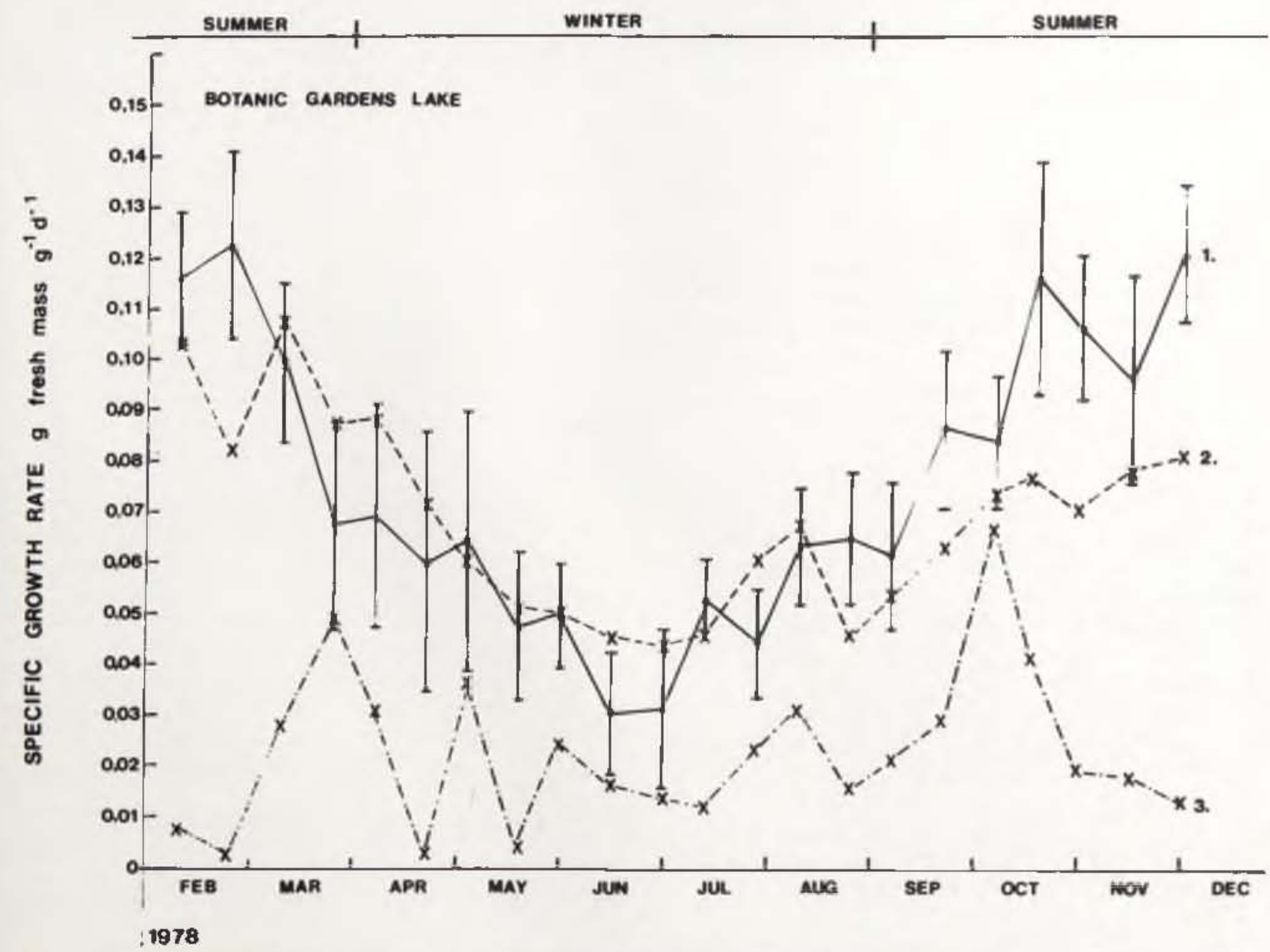

FIG. 13. - Specific growth rates predicted for marginal forms from 2, total $\mathrm{P}$ and 3 , SRP concentrations in the water, over each growing interval, at the Botanic Gardens Lake site compared with 1, measured specific growth rates. Standard deviations of measured specific growth rates are shown by bars. Umax values used in the Monod model derived under field conditions and expressed as a function of air temperature. 
species excrete alkaline phosphatases which may accelerate phytoplankton growth by supplying orthophosphate from suitable organic esters (Berman, 1969; 1970; Jansson, 1976; Wynne \& Gophen, 1981). The excretion of alkaline phosphatases by higher aquatic plant species has not been reported in the literature, though Wetzel $(1969 \mathrm{a}, 1969 \mathrm{~b})$ has shown that some species do excrete various dissolved organic compounds. One may, therefore, speculate that species such as $E$. crassipes may excrete alkaline phosphatases which would allow them to utilize normally unavailable organic forms of $\mathbf{P}$ for growth.

With respect to N, Sculthorpe (1967) suggested that $\mathrm{NH}_{4}-\mathrm{N}$ does not serve as an $\mathrm{N}$ source for growth of aquatic plants. However, several authors (Von Schwoerbel \& Tillmans, 1972; Toetz, 1971; 1973) have subsequently shown a preference by aquatic plants for $\mathrm{NH}_{4}-\mathrm{N}$ as an $\mathrm{N}$ source for growth. Best (1980) demonstrated that, although $\mathrm{NH}_{4}-\mathrm{N}$ supplied at low concentrations for a short period stimulated the growth of Ceratophyllum demersum L. in culture, higher concentrations (in excess of $45 \times 10^{3} \mu \mathrm{g}$ $\mathrm{NH}_{4}-\mathrm{N} \ell^{-1}$ ) applied for a prolonged period were toxic. The ammonium-induced inhibition of growth has been reported for several other aquatic macrophyte species (Mulligan et al., 1976). High $\mathrm{NH}_{4}-\mathrm{N}$ concentrations in the water may repress the induction of nitrate reductase as shown by Joy (1969) and Orebamjo \& Stewart (1975a, 1975b) in Lemna minor L. Reduced nitrate reductase activity would mean reduced $\mathrm{N}$ uptake and consequently a reduction in growth rate.
The largest differences between measured specific growth rates and those predicted from total $\mathrm{P}$ concentrations in the water at the BGL site (Fig. 13) occurred during the summer months (September to March) when radiant flux densities (diffuse component of the radiant flux) were high (Fig. 4). This sug* gested that if the effects of radiant flux density plus air temperature were incorporated into the model, it might improve its accuracy of prediction.

\section{Correcting Umax for radiant fux density}

An Arrhenius plot of specific growth rates (estimated Umax values) of marginal forms, expressed as natural logarithms ( $\left.\log _{k}\right)$, against the products of the reciprocals of absolute mean daily air temperatures and diffuse radiant fluxes at the MP3 site (Fig. 14), over the period February to December, 1978, yielded a linear relationship. The correlation coefficient $(r=0,8329)$ obtained was highly significant $(P \geqslant 0,001)$ and higher than that $(r=0,8089)$ obtained for the regression of estimated Umax values against temperature only (Fig. 13). The regression equation obtained for this exponential relationship was:

$$
\mathrm{U}=0,2574 e^{-107 \mathrm{~T}} \times \mathrm{DRF} .
$$

where $\mathrm{U}=$ specific growth rate (estimated maximum specific growth rate) $\mathrm{g}$ fresh mass $\mathrm{g}^{-1} \mathrm{~d}^{-1} ; \mathrm{T}=$ absolute mean daily air temperature ${ }^{\circ} \mathrm{K}$; DRF $=$ diffuse component of the radiant flux $M J m^{-2} h^{-1}$.

Substituting Equation 5 for Equation 3 in the Monod model, specific growth rates were repre-

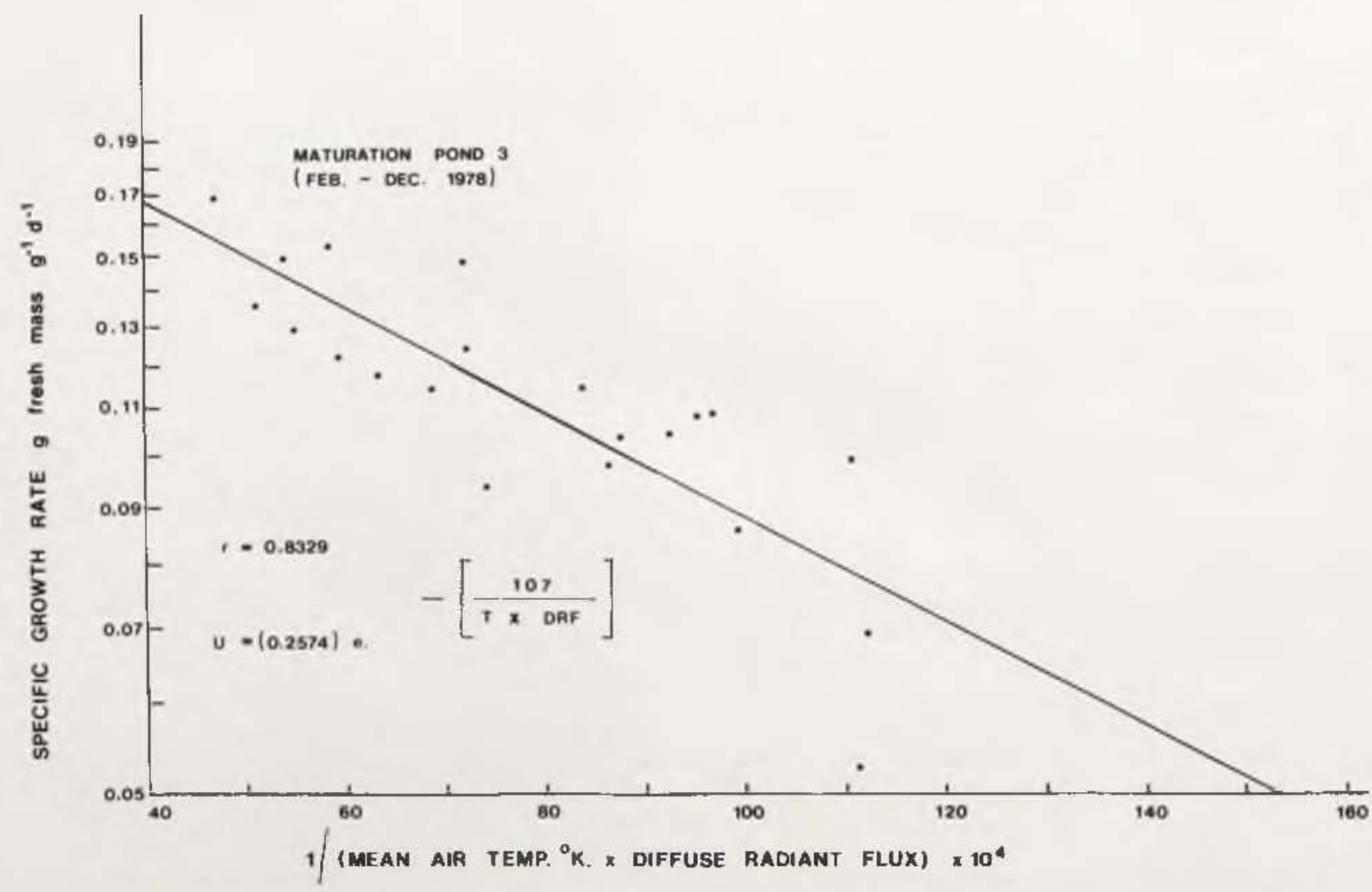

FIG. 14. - An Arrhenius plot of specific growth rates (estimated Umax values) of marginal forms (Log, against the products of the reciprocals of absolute mean daily air temperatures and diffuse radiant fluxes at the maturation pond 3 site. 


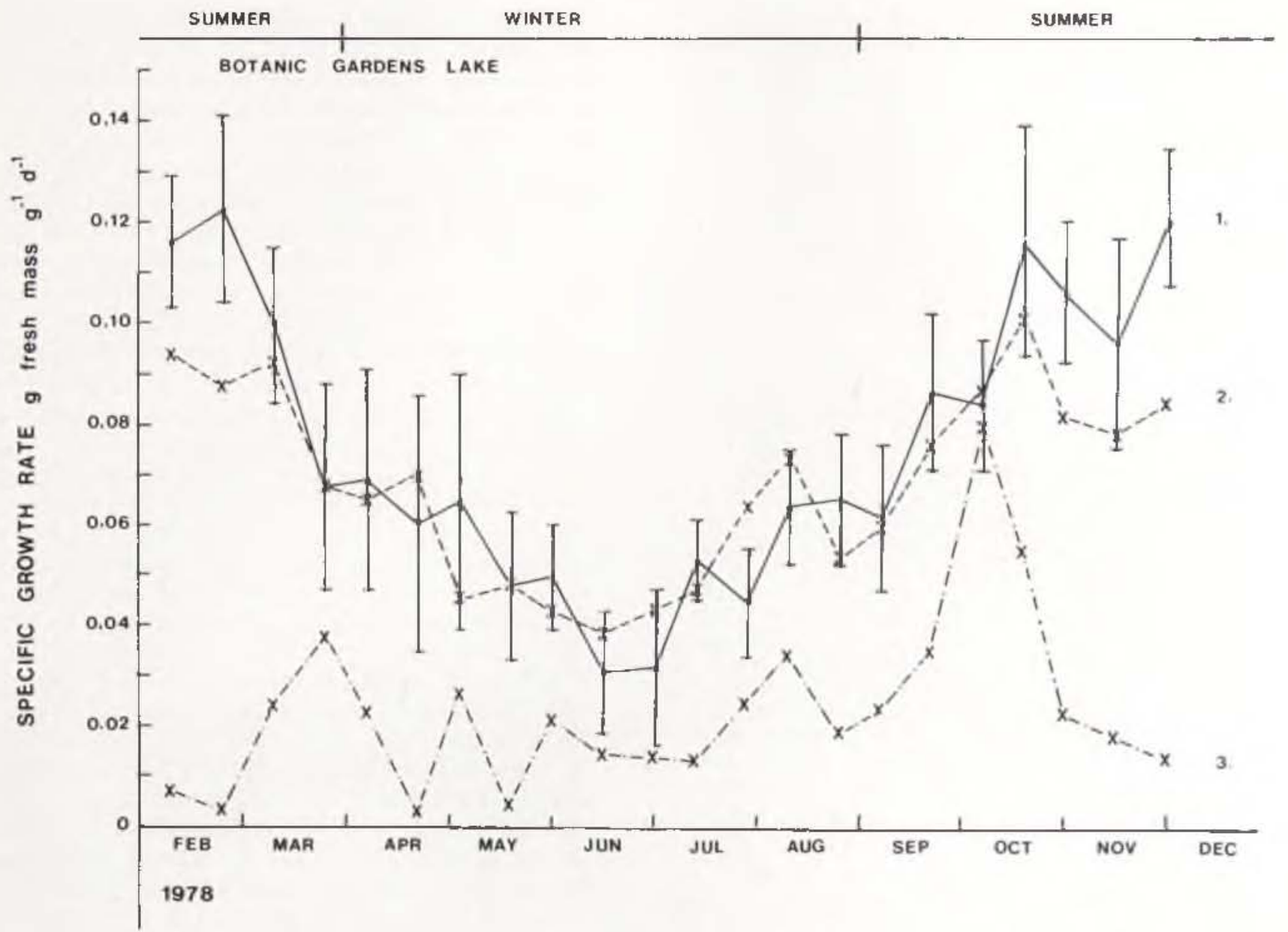

FIG. 15. - Specific growth rates predicted for marginal forms from 2, total P and 3, SRP concentrations in the water, over each growing interval, at the Botanic Gardens Lake site compared with 1, measured specific growth rates. Standard deviations of measured specific growth rates are shown by bars. Umax values used in the Monod model derived under field conditions and expressed as a function of ait temperature and diffuse radiant flux.

dicted for marginal forms at the BGL site from the limiting $\mathrm{P}$ (SRP and total P) concentrations in the water, mean daily air temperatures and diffuse radiant fluxes.

Predicted specific growth rates and those measured for marginal forms are illustrated in Fig. 15.

In general, specific growth rates were more accurately predicted from the limiting total $P$ concentrations in the water at the BGL site using Equation 5 in the Monod model than Equation 3. In the former example, 15 of the 22 specific growth rates predicted from total $P$ concentrations in the water (ca $68 \%$ ) fell within the standard deviations of measured growth rates (Fig. 15), compared with 14 (ca 64\%) in the latter (Fig. 13). However, the coefficient of variation $\left(R^{2}\right)$ calculated between measured and predicted values was considerably higher in the former example $\left(\mathbf{R}^{2}=0,7973\right)$ than in the latter $\left(R^{2}=\right.$ 0,5321 ). Furthermore, the differences between measured and predicted values were also generally much smaller in the former example than in the latter (Table 3). Similar results were obtained at sites where $\mathrm{N}$ was estimated to be the limiting nutrient (Musil, 1982). In both examples, specific growth rates were more accurately predicted from total $\mathrm{N}$ or total $\mathbf{P}$ concentrations than from other $\mathbf{N}$ or $\mathbf{P}$ fractions in the water.
The largest differences between measured specific growth rates and those predicted from total $\mathrm{P}$ concentrations in the water at the BGL site (Fig. 15) occurred during midsummer (November to February) when relative humidities were highest (Fig. 3 ). This suggested that if the effects of relative humidity, in addition to air temperature plus radiant flux density, were incorporated into the model, it might further improve its accuracy of prediction.

\section{Correcting Umax for relative humidiry}

An Arrhenius plot of specific growth rates (estimated Umax values) of marginal forms, expressed as natural logarithms $\left(\log _{e}\right)$, against the products of the reciprocals of absolute mean daily air temperatures, diffuse radiant fluxes and mean daily relative humidities at the MP3 site (Fig. 16), over the period February to December, 1978 , yielded a linear relationship. The correlation coeffient $(r=0,8567)$ obtained was highly significant $(P \geqslant 0,001)$. It was higher than that obtained for the regression of estimated Umax values against the products of temperaturc and diffuse radiant flux $(r=0,8329)$ or temperature only $(r=0,8089)$. The regression equation obtained for this exponential relationship was:

$\mathrm{U}=0,2247 e^{-7000 / \mathrm{T}} \times \mathrm{DRF} \times \mathrm{RH}$ 
TABLE 3. - A comparison of differences between measured specific growth rates and those predicted from limiting to tal $P$ concentrations in the water at the Botaric Gardens Lakc site, where predicted values were calculated using Limax values, in the Monod model, expressed as a function of:

A. air temperature,

B. ais temperature and diffuse radiant flux

\begin{tabular}{|c|c|c|}
\hline \multirow{2}{*}{$\begin{array}{c}\text { Growing } \\
\text { interval } \\
\text { dates }\end{array}$} & \multicolumn{2}{|c|}{$\begin{array}{c}\text { Differences } \\
\mathrm{g} \text { fresh mass } \mathrm{g}^{-1} \mathrm{~d}^{-1}\end{array}$} \\
\hline & A & B \\
\hline $01 / 02-15 / 02 / 78$ & $* 0,0128$ & 0,0212 \\
\hline $17 / 02-01 / 03 / 78$ & 0,0406 & $* 0,0316$ \\
\hline $02 / 03-14 / 03 / 78$ & 0,0082 & $* 0,0065$ \\
\hline $16 / 03-28 / 03 / 78$ & 0,0199 & $* 0,0019$ \\
\hline $31 / 03-12 / 04 / 78$ & 0,0199 & $* 0,0036$ \\
\hline $14 / 04-25 / 04 / 78$ & 0,0114 & $* 0,0110$ \\
\hline $28 / 04-09 / 05 / 78$ & $* 0,0037$ & 0,0186 \\
\hline $12 / 05-23 / 05 / 78$ & 0,0035 & $* 0,0003$ \\
\hline $26 / 05-06 / 06 / 78$ & $* 0,0011$ & 0,0078 \\
\hline $09 / 06-20 / 06 / 78$ & 0,0151 & $* 0,0147$ \\
\hline $23 / 06-04 / 07 / 78$ & $* 0,0127$ & 0,0133 \\
\hline $07 / 07-18 / 07 / 78$ & 0,0068 & $* 0,0056$ \\
\hline $20 / 07-02 / 08 / 78$ & 0,0162 & 0,0177 \\
\hline $04 / 08-15 / 08 / 78$ & 0,0040 & $* 0,0030$ \\
\hline $18 / 08-29 / 08 / 78$ & 0,0196 & $* 0,0161$ \\
\hline $01 / 09-13 / 09 / 78$ & 0,0079 & $* 0,0004$ \\
\hline $15 / 09-27 / 09 / 78$ & 0,0234 & $* 0,0113$ \\
\hline $29 / 09-11 / 10 / 78$ & 0,0105 & $* 0,0039$ \\
\hline $13 / 10-23 / 10 / 78$ & 0,0391 & $-0,0131$ \\
\hline $25 / 10-07 / 11 / 78$ & 0,0356 & $* 0,0252$ \\
\hline $10 / 11-22 / 11 / 78$ & $* 0,0177$ & 0,0185 \\
\hline $24 / 11-06 / 12 / 78$ & 0,0394 & $* 0,0348$ \\
\hline
\end{tabular}

- smallest difference where $U=$ specific growth rate testimated maximum specific growth rate) $g$ fresh mass $g^{-1} \mathrm{~d}^{-1} ; \mathrm{T}=$ absolute mean daily air temperature ${ }^{\circ} \mathrm{K} ; \mathrm{DRF}=$ diffuse component of the radiant flux MJ m.2 $\mathrm{h}^{-1} ; \mathrm{RH}=$ mean daily relative humidity.

Substituting Equation 6 for Equation 5 in the Monod model, specific growth rates were repredicted for marginal forms at the BGL site from the limiting $\mathbf{P}$ (SRP and total P) concentrations in the water, mean daily air temperatures, diffuse radiant fluxes and mean daily relative humidities. Predicted specific growth rates and those measured for marginal forms are illustrated in Fig. 17.

In general, specific growth rates were predicted with similar accuracy from the limiting total $\mathrm{P}$ concentrations in the water at the BGL site using Equation 6 in the Monod model compared with Equation 5. In the former example, 17 of the 22 specific growth rates predicted from total $P$ concentrations in the water (ca $77 \%$ ) fell within the standard deviations of measured specific growth rates (Fig. 17), compared with 15 (ca 68\%) in the latter (Fig. 15). However, the coefficients of variation $\left(\mathrm{R}^{2}\right)$, and the differences calculated between measured and predicted values (Table 4 ), were not very much different in the former example $\left(R^{2}=0,7870\right)$ compared with the latter $\left(\mathrm{R}^{2}=0,7973\right)$. Similar results were obtained at sites where $\mathrm{N}$ was estimated to be the limiting nutrient (Musil, 1982). In both examples, specific growth rates were more accurately predicted from total $\mathrm{N}$ or total $\mathrm{P}$ concentrations, than from other $\mathrm{N}$ or $\mathrm{P}$ fractions, in the water.

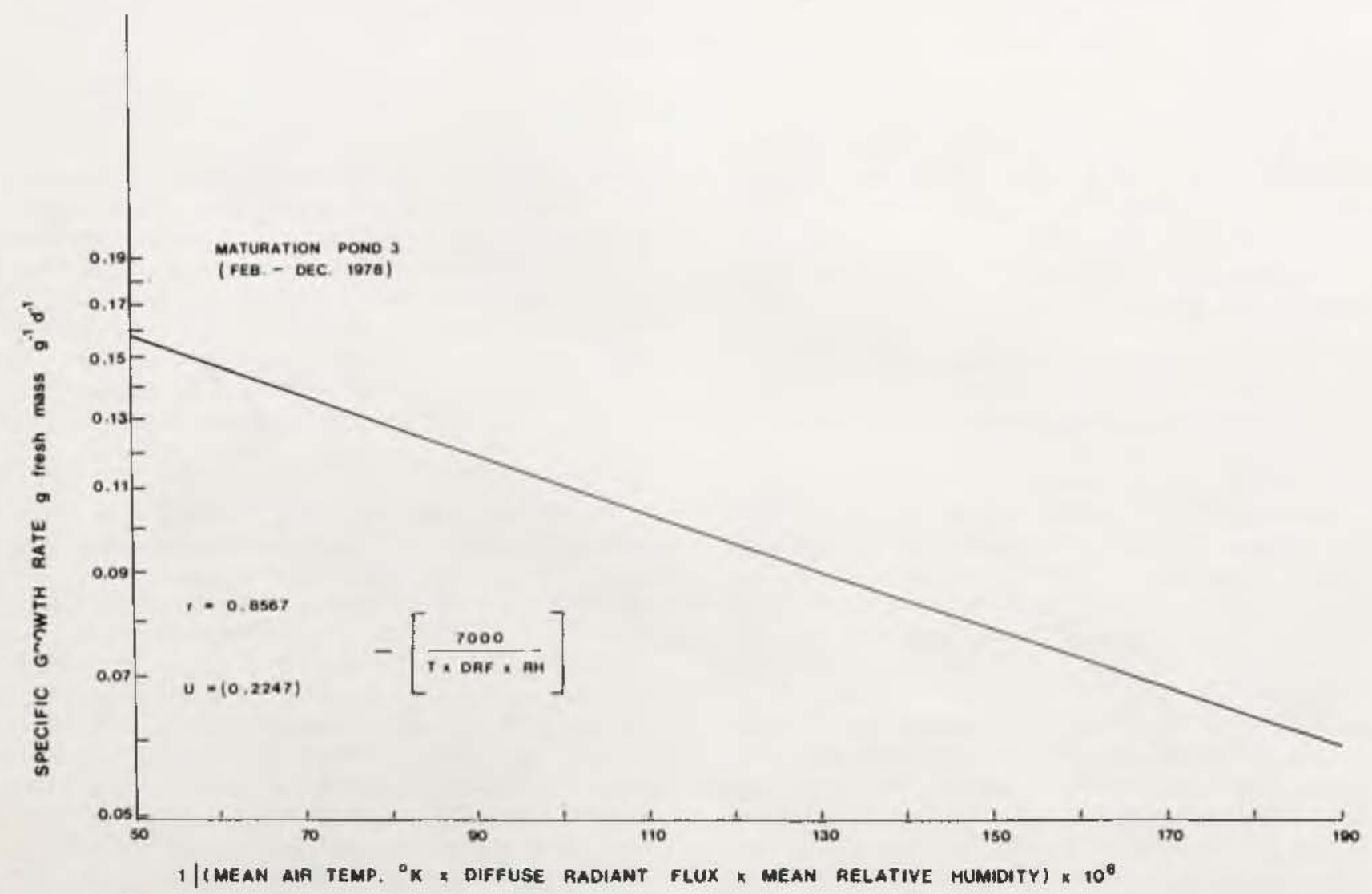

FIG. 16. - An Arrhenius plot of specific growth rates (estimated Umax values) of marginal forms (Log) against the products of the reciprocals of absolute mean daily air temperatures, diffuse radiant fluxes and mean daily relative humidities at the maturation pond 3 site. 


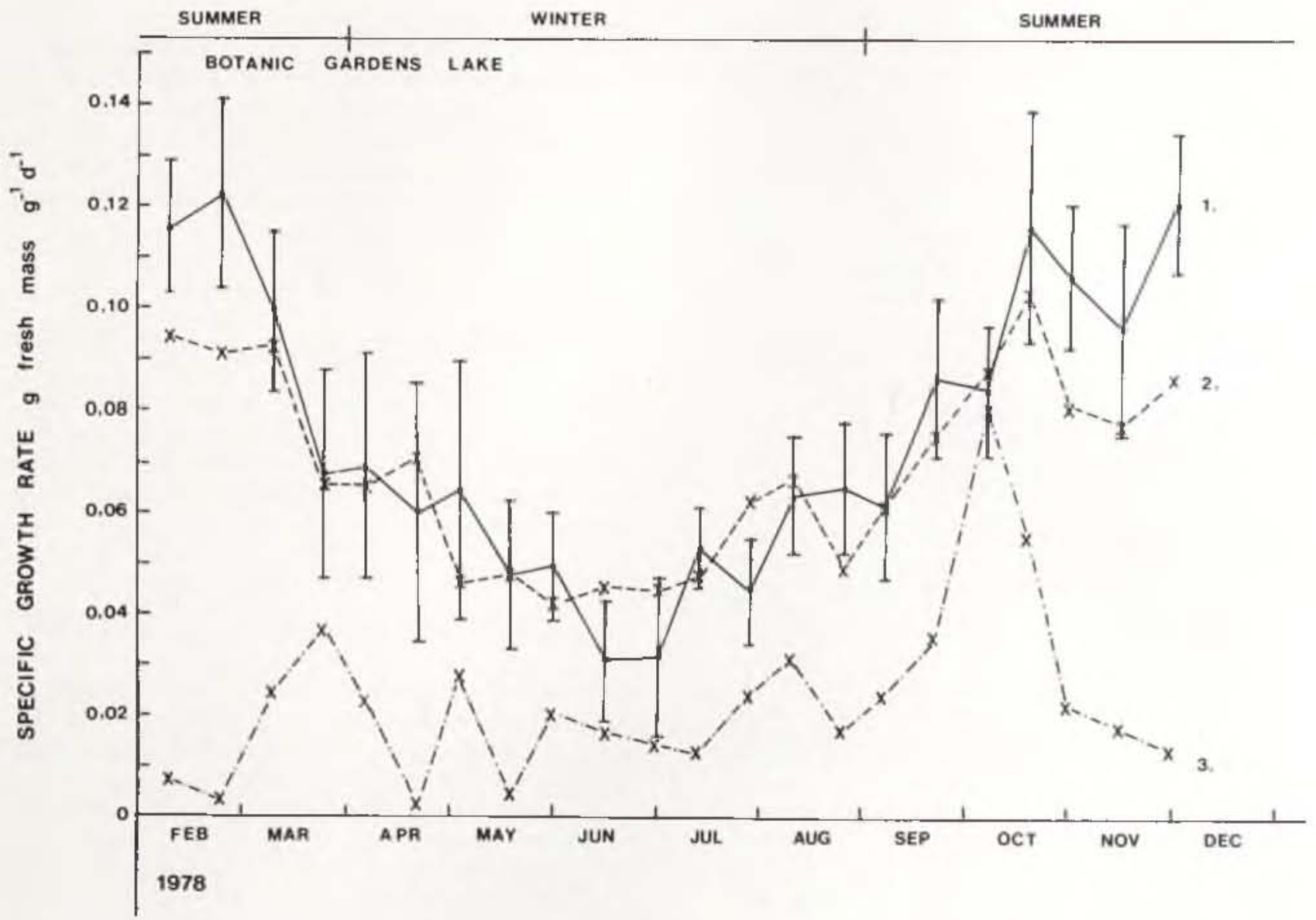

FIG. 17. - Specific growth rates predicted for marginal forms from 2, total P and 3, SRP concentrations in the water, over each growing interval, at the Botanic Gardens Lake site compared with 1, measured specific growth rates. Standard deviations of measured specific growth rates are shown by bars. Umax values used in the Monod model derived under field conditions and expressed as a function of air temperature, diffuse radiant flux and relative humidity.

The largest differences between measured specific growth rates and those predicted from total $\mathrm{P}$ concentrations in the water at the BGL site (Fig. 17), however, still occurred during midsummer (November to February). It appeared unlikely that the water $\mathrm{pH}$ significantly influenced $E$. crassipes growth rate at this site or at the MP3 site from where the Umax values of marginal forms were derived. The recorded variation in the water $\mathrm{pH}$ at these two sites (Fig. 7) being considerably smaller than the variation in $\mathrm{pH}$ of ca $1,2 \mathrm{pH}$ units or greater, in the range pH 3,0 to 8,2 shown by Chadwick \& Obeid (1966) as significantly influencing $E$. crassipes growth in culture. In addition, the water $\mathrm{pH}$ values at both sites were in close proximity to $\mathrm{pH} 7,0$ at which maximum growth of $E$. crassipes occurs (Chadwick \& Obeid, 1966). In view of this, two possible reasons are given to explain why predicted specific growth rates were significantly lower than those measured during midsummer:

(i) That the Ks concentrations derived for $E$. crassipes under culture conditions of $\mathrm{N}$ and $\mathrm{P}$ limitation (Musil \& Breen, 1985) were temperature dependent. In Chlorella pyrenoidosa and Oscillatoria agardhii, Shelef et al. (1970) and Ahlgren (1978) have shown that Ks varies with temperature. Similarly, in Aerobacter aerogenes and Escherichia coli, Topiwala \& Sinclair (1971) and Sawada et al. (1978) have also demonstrated that $\mathrm{Ks}$ changes with tem- perature and an Arrhenius plot of the change is linear. Lower Ks concentrations in the water for the specific limiting nutrient during midsummer, when temperatures were highest, would have brought the predicted specific growth rates closer to those measured. Consequently, it may be possible to describe more accurately the effect of a limiting nutrient on $E$. crassipes growth rate by expressing $\mathrm{Ks}$ as a function of temperature.

(ii) That the specific growth rates (estimated Umax values) measured for marginal forms at the MP3 site, particularly during midsummer, may have been depressed by some toxic factor in the water. High phytoplankton population densities in the water at the MP3 site, particularly during midsummer, may have resulted in the excretion by phytoplankton of some toxic factor in sufficiently high concentrations to be inhibitory to $E$. crassipes growth rate. Algae in some instances can severely interfere with the growth of higher plants (Hewitt, 1966), possibly through the production of antibiotic substances (Jorgensen, 1962) or toxic amino and carboxylic acids (Steinberg, 1947a; 1947b; Woltz \& Jackson, 1961; Woltz, 1963). Furthermore, the presence of phenolic acids, common by-products of decomposition, in the secondary treated waste-water effluent at the MP3 site may also have inhibited $E$. crassipes growth rate. Glass $(1973,1974)$, for example, has shown that phenolic acids severely inhibit 
TABLE 4,-A compasison of differences between measured specific growth rates and those predicted from limiting total P concentrations in the water at the Botanic Gardens Lake site, where predicted values were calculated using Umax values, in the Monod model, expressed as a function of: A. air temperature and diffuse radiant flux,

B. air temperature, diffuse radjant flux and relative humid ity

\begin{tabular}{|c|c|c|}
\hline \multirow{2}{*}{$\begin{array}{c}\text { Growing } \\
\text { interval } \\
\text { dates }\end{array}$} & \multicolumn{2}{|c|}{$\begin{array}{l}\text { Differences } \\
\mathrm{g} \text { fresh mass } \mathrm{g}^{-1} \mathrm{~d}^{-1}\end{array}$} \\
\hline & A & B \\
\hline $01 / 02-15 / 02 / 78$ & $* 0,0212$ & 0,0223 \\
\hline $17 / 02-01 / 03 / 78$ & 0,0316 & 0,0351 \\
\hline $02 / 03-14 / 03 / 78$ & $+0,0065$ & 0,0074 \\
\hline $16 / 03-28 / 03 / 78$ & 0,0019 & $* 0,0000$ \\
\hline $31 / 03-12 / 04 / 78$ & 0,0036 & 0,0040 \\
\hline $14 / 04-25 / 04 / 78$ & 0,0110 & $* 0,0099$ \\
\hline $28 / 04-09 / 05 / 78$ & $* 0,0186$ & 0,0198 \\
\hline $12 / 05-23 / 05 / 78$ & $* 0,0003$ & 0,0007 \\
\hline $26 / 05-06 / 06 / 78$ & 0,0078 & $\bullet 0,0067$ \\
\hline $09 / 06-20 / 06 / 78$ & 0,0147 & 0,0079 \\
\hline $23 / 06-04 / 07 / 78$ & 0,0133 & $* 0,0120$ \\
\hline $07 / 07-18 / 07 / 78$ & 0,0056 & 0,0057 \\
\hline $20 / 07-02 / 08 / 78$ & $* 0,0177$ & 0,0192 \\
\hline $04 / 08-15 / 08 / 78$ & 0,0030 & 0,0100 \\
\hline $18 / 08-29 / 08 / 78$ & 0,0161 & $=0,0120$ \\
\hline $01 / 09-13 / 09 / 78$ & $* 0,0004$ & 0,0021 \\
\hline $15 / 09-27 / 09 / 78$ & 0,0113 & $+0,0107$ \\
\hline $29 / 09-11 / 10 / 78$ & 0,0039 & 0,0028 \\
\hline $13 / 10-23 / 10 / 78$ & $* 0,0131$ & 0,0147 \\
\hline $25 / 10-07 / 11 / 78$ & 0,0252 & $+0,0249$ \\
\hline $10 / 11-22 / 11 / 78$ & 0,0185 & 0,0181 \\
\hline $24 / 11-06 / 12 / 78$ & $\star 0,0348$ & 0,0363 \\
\hline
\end{tabular}

- smallest difference

the uptake of $\mathrm{P}$ and $\mathrm{K}$ by barley. Consequently, Umax values derived for $E$. crassipes at the MP3 site, under conditions of growth rate inhibition by some toxic factor in the water, when incorporated into the Monod model would have underestimated the specific growth rates of plants at the BGL site. This is what was observed during midsummer (Fig. 17).

Finally, it should be pointed out that at the BGL site relative humidities were not substantially different from the MP3 site, at which the Umax values of E. crassipes were derived. However, at sites where relative humidities were substantially different from the MP3 site, Musil (1982) showed that specific growth rates of marginal forms were generally more accurately predicted from the limiting nutrient concentrations in the water using Equation 6 in the Monod model than Equation 5.

\section{CONCLUSIONS}

Specific growth rates of $E$. crassipes growing in loosely crowded field populations were adequately predicted from the limiting total $N$ or total $P$ concentrations in the water using culture-derived half saturation coefficients (Ks) and field-derived maximum specific growth rates (Umax), expressed as a function of air temperature, diffuse radiant flux and relative humidity, in the Monod model. The possible temperature dependency of $\mathrm{Ks}$ requires further investigation. This, however, will require precise measurements of $\mathrm{Ks}$, under conditions of $\mathrm{N}$ or $\mathrm{P}$ limitation, at different temperatures in some type of continuous flow culture system, as suggested by Musil \& Breen (1985). The relationship between Ks and temperature will then need to be mathematically formulated and incorporated into the model. Whether such refinements will improve the model's accuracy of prediction needs verification.

\section{ACKNOWLEDGEMENTS}

We wish to thank Mr A. Zakwe and Mrs J. Schaap for technical services rendered; the City Engineer, Durban for providing facilities at the northern sewage treatment works; Prof. D.F. Toerien, Drs P.J. Ashton and M.C. Rutherford for their valuable comments and criticisms and Mrs S.S. Brink for typing the manuscript.

\section{UITTREKSEL}

Kinetiese koëffisiēnte afgelei vir Eichhornia crassipes (Mart.) Solms onder kultuurtoestande met $N$ en $P$ as beperkende faktore is in die Monodmodel gebruik om die beperkende voedingselement te identifi. seer en om die spesifieke groeitempo onder variērende voedingselementkonsentrasies en lugtemperature te voorspel. Voorspellings is korrek bewys deur vergelyking met gemete spesifieke groeitempo's van plantpopulasies wat of los of dig saamgepak by twee proefpersele groei. Die gebruik van kultuurafgeleide maksimum spesifieke groeitempo's ('Umax') in die model, het tot onakkurate voorspellings van plantegroeitempo's in los-en digsaamgepakte veldpopulasies gelei. Die gebruik van 'Umax'e' afgelei van veldtoestande in die model, het egter voldoende voorspellings van plantegroeitempo's in losgepakte veldpopulasies gegee. Die insluiting van stralingstroomdigtheid (diffuse komponent van die stralingstroom) en relatiewe vogtigheid in die model, het die akkuraatheid van voorspelling aansienlik verbeter. In alle gevalle, is spesifieke groeitempo's meer akkuraat van die beperkende totale $N$ of totale $P$ konsentrasies voorspel, as van ander $N$ of $P$ fraksies, in die water.

\section{REFERENCES}

AHLGREN, G., 1978. Growth of Oscillatoria agardhii in chemostat culture. 2. Dependence of growth constant on temperature. Mitt. int. Verein, theor, angew. Limnol. 21: $88-102$.

AMERICAN PUBLIC HEALTH ASSOCIATION, AMERICAN WATER WORKS ASSOCIATION AND WATER POLLUTION CONTROL FEDERATION, 1975. Standard methods for the examination of water and waste-water, 14th edn, pp. 1193. New York.

BEEVERS, L. \& COOPER, J.P., 1964. Influence of temperaeure on growth and metabolism of ryegrass seedlings. I. Seedling growth and yield components. Crop Sci. 4: $139-143$.

BEL.L, C.J., 1981. The testing and validation of models. In D.A. Rose \& D.A. Charles-Edwards, Mathematics and plant physiology, 229-30\%. London and New York: Academic Press.

BERMAN, $T_{+}$, 1969. Phosphatase release of inorganic phosphorus in Lake Kinneret. Nature, Lond. 224: 1231-1232.

BERMAN, T., 1970, Alkaline phosphatase and phosphorus availability in Lake Kinneret. Limnot. Oceanogr. 15: $663-674$.

BEST, E.P.H., 1980. Effects of nitrogen on the growth and nitrogenous compounds of Ceratophyllum demersum, Aquat. Bot. 8,2: $197-206$. 
BILLINGS, W.D., 1974. Arctic and alpine vegetation : plant ad aptations to cold summer climates. In J.D. Ives \& R.G Barry, Arctic and alpine environments, 403-443. London: Methuen.

BLACKMAN, F.F., 1905. Optima and limiting factors. Ann. Bot. 19: 28:-295.

BOCK, J.H., 1966. An ecological study of Eichhornia crassipes with special emphasis on its reproductive biology. Ph.D. thesis, University of California, Berkeley, I86 pp.

BOCK, J.H., 1969. Productivity of the water hyacinth (Eichhor nia crassipes). Ecology 50: 460-464.

BOYD, C.E., 1970. Vascular aquatic plants for mineral nutrient removal from polluted waters. Econ. Bot. 24: 95-103.

BOYD, C.E., 1976. Accumulation of dry matter, nitrogen and phosphorus by cuttivated water hyacinths. Econ. Bot. 30 : 51-56.

BRUHL, P. \& GUPTA, J.S., 1927. Commentationes phytomorphologicae. IV. Eichhornia studies. III. On the production of ripe seeds by artificial pollination of Eichhornia speciosa. J. Dep. Sci. Calcuta Univ. 8: 1-8.

CENTER, T.D. \& SPENCER, N.R., 1981. The phenology and growth of water hyacinth (Eichhornia crassipes (Mart.) Solms) in a eutrophic north-central Florida lake. Aquat. Bot. $10,1: 1-32$

CHADWICK, M.J. \& OBEID, M., 1966. A comparitive study of the growth of Eichhornia crassipes (Mart.) Solms and Pistia stratioses L in water culture. J. Ecol. 54: 563-575.

CHEN, C.W. \& ORLOB, G.T., 1972. Ecological simulation of aquatic environments. Final report of Office for Water Resources Research (OWRR C-2044), U.S. Department of Interior, Washington, $156 \mathrm{pp}$.

CRAFTS, A.S., CURRIER, H.B. \& STOCKING, C.R., 1949 Water in the physiology of plants. Waltham, Massachusetts: Chronica Botanica.

DENT, J.B. \& BLACKIE, M.J., 1979. Systems simulation in agriculure. Barking, USA: Applied Science Publishers.

DITORO, D.M., O'CONNER, D.J. \& THOMANN, R.V. 1971. A dynamic model of the phytoplankton populations in the Sacremento-San Joaquim Delta. Adv. Chem. Ser. 106: $131-180$.

DROOP, M.R., 1974. The nutrient status of algal cells in continuous culiure. J. mar. biol. Ass. U.K. 54: 825-855.

ENVIRONMENT AL PROTECTION AGENCY, 1974. Manual of methods for chemical analysis of water and wastes. $\mathrm{Re}$ port no. EPA-625/6-74-003. Washington, D.C.: U.S. Environmental Protection Agency Office of Technological Transfer.

FITTER, A.H. \& HAY, R. K.M., 1981. Environmental physiology of plants. London and New York: Academic Press.

EPPLEY, R.W., 1972. Temperature and phytoplankton growth in the sea. Fish Bull. Calif. 70: 1063-1085.

FREIDEL, J., KOCH, W. \& PHILIPP, O., 1978. Studies of the biology and population dynamics of Eichhornia crassipes (Mart.) Solms in the Sudan. Proceedings of the European Weeds Research Soctery Sth Symp. on Aguatic Weeds.

GALLAGHER, J.N. \& BISCOE, P.V.. 1979. Field studies of cereal leaf growth. III. J. exp. Bot. 117:645-655.

GLASS, A.D.M., 1973. Influence of phenolic acids on ion uptake. I. Inhibition of phosphate uptakc. Pl. Physiol. 51: $1037-1041$.

GLASS, A.D.M., 1974. Influence of phenolic acids on ion uptake. III. Inhibition of potassium absorption. J. exp. Bot. 25: $1104-1113$.

GOLDMAN, J.C., 1972. The kinesics of inorganic carbon limited growsh of green algae in continuous culture. Its relasionship to eutrophication. Ph.D. thesis, University of California, Berkeley.

GOLDMAN, J.C. \& CARPENTER, E.J., 1974. A kinetic approach to the effect of temperature on algal growth. Limnol Oceanogr, 19,5: 756-766.

GOLTERMAN, H.L., CLYMO, R.S. \& OHNSTAD, M.A.M. 1969. Methods for chemical analysis of fresh waters. 2nd edn Oxford, Edinburgh, London, Melbourne: Blackwell Scientific Publications.

GRAN, H.H., 1912. Pelagic plant life. In J. Murray \& J. Hjort, Depth of the ocean, 307-386. Weinhen: Cramer.

GREACEN, E.L. OH, J.S., 1972. Physics of root growth. Norure, Lond. (New Biol.) 235: 24-25.

HARRIS, G.P. \& LOTT, J.N.A., 1973. Light intensity and photosynthetic rates in phytoplankton. J. Fish. Res. Bd Can. 30: 1771-1778.
HAYES, F.R, \& PHILLIPS, J.E, 1968. Lake water and sediment. IV. Radio-phosphorus equilibrium with mud, plants and bacteria under oxidised and reduced conditions. Limnol. Oceanogr. 3: 459-475.

HEPHER, B., 1958. On the dynamics of phosphorus added to fish ponds in Israel. Limnol. Oceanogr. 3: 84-100.

HEWITT, E.J., 1966. Sand and water culture methods used in she study of plant nutrition. Farnham Royal, Bucks, England: Commonwealth Agricultural Bureau.

HSIAO, T.C.. ACEVEDO, E., FERERES, E. \& HENDER SON, D.W. 1976. Water stress, growth and osmotic ad justment. Phil. Trans. R. Soc. B273: 479-500.

JANSSON, M., 1976. Phosphatases in lake water: characterization of enzymes from phytoplankton and zooplankton by gel filtration. Science 194: 320-321.

JESCHKE, W.D. \& SIMONIS, W. . 1965. Uber dic Aufnahme von Phosphatund, Sulphationem durch Blātter von Elodea densa und inhre Beeinflussung durch Licht, Temperatur und Aussen-konzentration. Planta 67: 6-32.

JORGENSEN, E.G., 1962. Antibiotic substances from cells and culture solutions in unicellular algae with special reference to some chlorophyll derivatives. Physiologia Pl. 15: 530 .

JOY, K.W.. 1969. Nitrogen metabolism of Lemna minor. I. Growth, nitrogen sources and amino acid inhibition. Pl. Physiol. 44: 845.

KIEFER, D.A. \& ENNS, T., 1976. A steady-state model of lighttemperature-and carbon-limited growth of phytoplankion. In R.P. Canale, Modelling biochemical processes in aquatic ecosystems, 319-336. Michigan: Ann Arbor Sci.

KNIPLING, E.B.. WEST, S.H. \& HALLER, W.T., 1970 Growth characteristics, yield potential and nutrient content of water hyacinths. Soil Crop Sci Soc. Fla 30: 51-63.

LA GARDE, R.V., 1930. A plant that stopped navigation. Bull. Mo. bor. Gdn 18: 48-51.

LANSDELL, K.A., 1925. The water hyacinth, Etchtornia speciosa Kunth. J. Dep, Agric. Un. S. Afr. 10: 24-28.

MADDUX, W.S. \& JONES, R.F., 1964. Some interactions of temperature, light intensity and nutrient concentrations during the continuous culture of Nitzschia closterium and Teiraselmis sp. Limnol. Oceanogr. 9: 79-86.

MALEK, I. \& FENCL, Z., 1966. Theoretical and methodological basis of consinuous culture of micro-organisms. Prague: Czechoslovak Academy of Sciences.

McLEAN, K., 1922. Water hyacinth. A serious pest in Bengal. Agric, J. India 17: 23-40.

MEIDNER, H. \& SHERIFF, D.W., 1976. Water and plants. Glasgow: Blackie.

MITSCH, W.J., 1977. Water hyacinth (Eichhornia crassipes), nutrient uptake and metabolism in a north central Florida marsh. Arch. Hydrobiol. 81: 188-210.

MORRIS, T.L., 1974, Water hyacinth Eichhornia crassipes (Mart.) Solms: its ability to invade aquatic ecosystems of Payne's Prairie Preserve. M.S. thesis, University of Florida, Gainesville, FL., 135 pp.

MULLIGAN, H.F., BARANOWSKY, A. \& JOHNSON, R., 1976. Nitrogen and phosphorus fertilization of aquatic vascular plants and algae in replicated ponds. I. Initial response to fertilization. Hydrobiologia 48: 109-116.

MUSIL, C.F., 1982. The use of growth kinetics in the development of a predictive model for the growth of Eichhornia crassipes (Mart.) Solms in the field. Ph.D. thesis, Unjversity of Natal.

MUSIL, C.F. \& BREEN, C.M., 1977. The application of growth kinetics to the control of Eichhornia crassipes (Mart.) Solms through nutrient removal by mechanical harvesting. Hydrobiologia 53,2: 165-171.

MUSIL, C.F. \& BREEN, C.M., 1985. The development from kinetic coefficients of a predictive model for the growth of Eichhornia crassipes in the field. I. Generating kinetic coefficients for the model in greenhouse culture. Bothalisa 15: 689-703.

O'BRIEN, W.J., 1972. Limiting factors in phytoplankton algae: their meaning and measurement. Science 178: 616-617.

OLSEN, S., 1967. Recent trends in the determination of phosphate in the aquatic environment. In H.L. Golterman and R.S. Clymo, Chemical environment in the aquatic habisat, 63-105. Proceedings of an IBP symposium, 10-16 October, 1966. Amsterdam: Royal Netherlands Academy of Sciences. 
OREBAMJO, T.O. \& STEWART, G.R., 1975a. Ammonium Tepression of nitrate reductase formation in Lemma minor $\mathrm{L}$. Plania 122: 27-36.

OREBAMJO, T.O. \& STEWART, G.R., 1975b. Ammonium inactivation of nitrate reductase in Lemna minor L. Planta 122: $37-44$.

PARK, R.A., SCAVIA, D. \& CLESCERI, N.L., 1975 CLEANER: the Lake George Model. In C.S. Russel, Ecological madelling in a resource management framework, 49-82. Washington, D.C: Resources for the Future, Inc.

PISEK, A., LARCHER, W.. VEGIS, A. \& NAPP-ZIN, K., 1973. The normal temperature range. In $\mathrm{H}$. Precht, J. Christopherson, H. Hensel \& W. Larcher, Temperature and life, 102-194, Berlin; Springer-Verlag.

POMEROY, L.R., SMITH, E.E. \& GRANT, C.M., 1965. The exchange of phosphate between estuarine water and sediments. Limnol. Oceanogr. 10: 167-172.

RADFORD, P.J, 1967. Growth analysis formulae - their use and abuse. Crop Sci. 7: 171-175.

RAO, P.S.J., 1920. The formation of leaf bladders in Eicithornia speciosa Kunth (water hyacinth), J. Indian Bot. 1: $219-225$.

RHEE, G-Y., 1978. Effects of N: P atomic ratios and nitsate limitation on algal growth, cell composition and nisrate uptake. Limnol. Oceanogr. 23,1: 10-25.

RIGLER, F.H., 1964. The phosphorus fractions and turnover time of phosphors in different types of Jakes. Limnol. Oceanogr, 9: 511-518.

RODHE, W., 1948. Environmental requirements of fresh-water plankion algae. Symb. bot. upsal. 10: 1-149.

RODHE, W. 1978. Algae in culture and nature. Mitt. int. Verein. theor. angew. Limnol. 21: 7-20.

ROSS, J., 1975. Radiant transfer in plant communities. In J.L. Monteith, Vegetation and the armosphere, Vol. t. Principles, 13-55. London, New York, San Francisco: Academic Press.

SAWADA, T., CHOHJI. T. \& KUNO, S., 1978. Kinetic analysis of unbalanced bacterial growth in temperature shift. In V.W. Weekman, Ir \& D. Luss, Chemical reaction engineering, 163-172. Washington D.C.: American Chemical Society.

SCHULZE, B.R., 1965. Climate of Sowth Africa. Part 8. Generat Survey. The Government Printer and Weather Burcau, RSA, 330 po.

SCHULTHORPE, C.O., 1967. The biology of aytatic vascular plants. London: Arnold.

SEAMAN, D.E. \& PORTERFIELD, W.A., 1964. Control of aquatic weeds by the snail Marisa cornaurietis. Weeds 12: $87-92$.

SHELEF, G., OSWALD. W.J. \& GOLUEKE, C.G., 1970. Assaying algal growth with respect to nitrate concentration by a cuntinuous flow turbidostat. Adv. Water Pollut, Res. 2:1-9. Oxford: Pergamon.

SLAYTER, R.O., 1967. Plant-water relationships. London and New York: Academic Press.
SMAYDA, T.J., 1969. Experimental observations on the influence of rempcrature, light and salinity on cell division of the marine diatom Detonula confervaceae (Cleve) Gran. $J$. Phycol. 5: $150-157$

SOROKIN, C., 1960. Kinetic studies on temperature effects on the cellular level. Biochim. biophys. Acta. 38: 197-204.

SOROKIN, C. \& KRAUSS, R.W., 1962. Effects on temperature and illuminance on Chlorella growth uncoupled from cell division. Pl. Physiol. 37: 37-42.

STEINBERG, R.A., 1947a, Growth responses to organic compounds by tobacco seedtings in aseptic culture. $f$. agric, Res. 75: 81.

STEINBERG. R.A., 1947b. Growth responses of tobacco seedlings in aseptic culture to diffusates of some common soil bacteria, $\boldsymbol{J}$. agric. Res. 75: 199.

SZE1CZ, G., 1974. Solar radiation in crop canopies. J. appl. Ecol. 11: 1117-1156.

TOERIEN, D.F., 1972. Nutrient removal as a means of control of Eichhornia crassipes. CSIR. National Institute for Water Rescarch, Pretoria. Report No. W3/24/1/16.

TOETZ, D.W., 1971. Diurnal uptake of $\mathrm{NO}_{3}$ and $\mathrm{NH}_{4}$ by a Cerarophyllum community. Limnol. Oceanogr. 16: 819-822.

TOETZ, D.W., 1973. The kinetics of $\mathrm{NH}_{4}$ uptake by Ceratophylhum. Hydrobiologia 41: 275-290.

TOPIWALA. H. \& SINCLAIR, C.G., 1971. Temperature relationship in continuous culture. Biotechnol. Bioeng. Symp. 13: 795-813.

TWINCH, A.A. \& BREEN, C.M., 1980. Advances in understanding phosphorus cycling in inland waters - their significance for South African iimnology. South African National Scientific Programmes, Report No. 42.

VON SCHWOERBEL, J, \& TILLMANS, G.C., 1972. Ammo. nium-adaptation bei submersen phanerogamen in situ. Arch. Hydrobiol. Suppl. 42: 139-141.

WEBER, H., 1950. Morphologische and anatomische Studien uber Eichhornia crassipes (Mart,) Solms. Abh. ath. Kl. Akad. Wiss. Mainz 6: 135-161.

WETZEL. R.G., 1969a. Excretion of dissolved organic compounds by aquatic macrophytes. Bioscience $19 ; 539-540$.

WETZEL, R.G., 1969b. Factors influencing photosynth-sis and excretion of dissolved organic matter by aquatic macrophytes in hard-water lakes. Verh. in. Verein. theor. angew. Limnot. 17: 72-85.

WOLTZ. S.S. 1963. Growth modifying and anti-metabolite effects of amino acids on chrysanthemum. Plant Physiol. $38: 93$.

WOLTZ, S.S. \& JACKSON, C.R., 1961. Production of yellow strap leaf of chrysanthemum and similar disorders by amino acid treatment. Plant Physiol. 36:197.

WYNNE, D, \& GOPHEN, M, 1981. Phosphatase activity in freshwater zooplankton. Oikos 37: 369-376.

YOUNT, J.L. \& CROSSMAN, R.A. Jr, 1970. Eurrophication control by plant harvesting. $\&$. Wat. Pollus. Control Fed. 42: $173-183$. 